\title{
An invertebrate macrofauna from an early Holocene fjord-delta system, North Norway
}

\author{
Jan KResten Nielsen, Jesper Kresten Nielsen, Kenneth EVison, Nils-Martin HankEN \& \\ SAMULI HELAMA
}

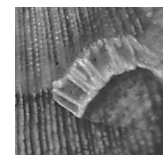

\begin{abstract}
During early Holocene, the Breivikeidet Valley of Troms County was part of a fjord system. Prodelta and delta slope deposits were formed, overlain by fluvial deposits, and are presently exposed in river sections. The depositional setting was influenced by sediment suspension and traction processes. Our geochemical analyses, together with implications from macrofauna and sedimentology, indicate an overall change from occasionally oxygen deficiency in marine waters to an overall fall in salinity, these changes finally leading to brackish and freshwater conditions. Radiocarbon dates confirm an early Holocene age (Preboreal, Boreal and Atlantic) of the deposits. Shells reworked from older deposits indicate Allerød and Younger Dryas ages. Bivalves, gastropods and barnacles are common and well preserved in the muddy prodelta deposits, whereas they are uncommon and poorly preserved in the delta slope sands. Faunal composition of the delta slope sands is numerically characterised by suspension-feeding endobenthos that have moderate to fast burrowing ability. The fossil macrofauna of the muddy prodelta deposits, on the other hand, can be much more diverse, including mobile to stationary endobenthos and epibenthos. The prodelta muds were close to normal marine in their salinity. The delta slope sands were probably somewhat brackish, while the topsets were formed in fluvial freshwater. Faunal composition indicates water depth of the ancient habitat having been equivalent to nearshore shelf to fjord-deltaic setting. A fjord-deltaic setting is evident by the sedimentology and adjacent steep topography. We conclude that the fossil macrofauna is in composition comparable with modern marine communities of the high-boreal province. $\bullet$ Key words: molluscs, barnacles, radiocarbon, geochemistry, depositional conditions, benthic communities, bioprovinces.
\end{abstract}

NiElsen, J.K., NiElSEN, J.K., Evison, K., HANKEN, N.-M. \& Helama, S. 2018. An invertebrate macrofauna from an early Holocene fjord-delta system, North Norway. Bulletin of Geosciences 93(1), $27-52$ (11 figures, 6 tables). Czech Geological Survey, Prague. ISSN 1214-1119. Manuscript received May 22, 2017; accepted in revised form September 20, 2017; published online March 28, 2018; issued March 31, 2018.

Jan Kresten Nielsen, VNG Norge AS, Filipstad Brygge 1, NO-0252 Oslo, Norway; taphofacies@ hotmail.com•Jesper Kresten Nielsen, MOL Norge AS, Trelastgata 3, NO-0191 Oslo, Norway・Kenneth Evison, Baker Hughes Norge AS, Tanangervegen 501, NO-4056 Tananger, Norway • Nils-Martin Hanken, Department of Geosciences, University of Oslo, P.O. Box 1047, Blindern, NO-0316 Oslo, Norway \& Department of Geology, UiT - the Arctic University of Norway, NO-9037 Tromsø, Norway - Samuli Helama, Natural Resources Institute Finland, P.O. Box 16, FI-96301, Rovaniemi, Finland

Fjord systems are abundant along the present coast of northern Norway, as confinements outlined by steep topography. Clastic sediments are formed by erosion of these mountains and transported by rivers into deltaic depositional systems within the fjords becoming redistributed by waves and tidal currents. The deltaic setting is characterised by varying environmental conditions in forms of river water charge, tide and waves. Such stressful conditions of short-term fluctuations in sedimentation, salinity and temperature affect the living animals (e.g. Hedgpeth 1957, Boesch \& Rosenberg 1981) and their past variations are reflected in faunal remains from ancient deltaic successions. Early Holocene successions, exposed in river sections along Breivikelva and Nakkeelva in the Troms County, North Norway (Fig. 1), have previously been investigated for sedimentology (e.g. Møller et al. 1986, Corner \& Fjalstad 1993, Nielsen et al. 2004, Evison 2012). Previous faunal investigations from these deposits have focused only on the microstructural and incremental chronologies obtained from Arctica islandica shells unearthed from Preboreal section in one of the successions (Helama et al. 2014, 2015). A much broadened view is, however, required to understand the development of faunal communities through the early Holocene variations demonstrated for the physical environment of this setting (Nielsen et al. 2004, Evison 2012). To this end, the successions containing 


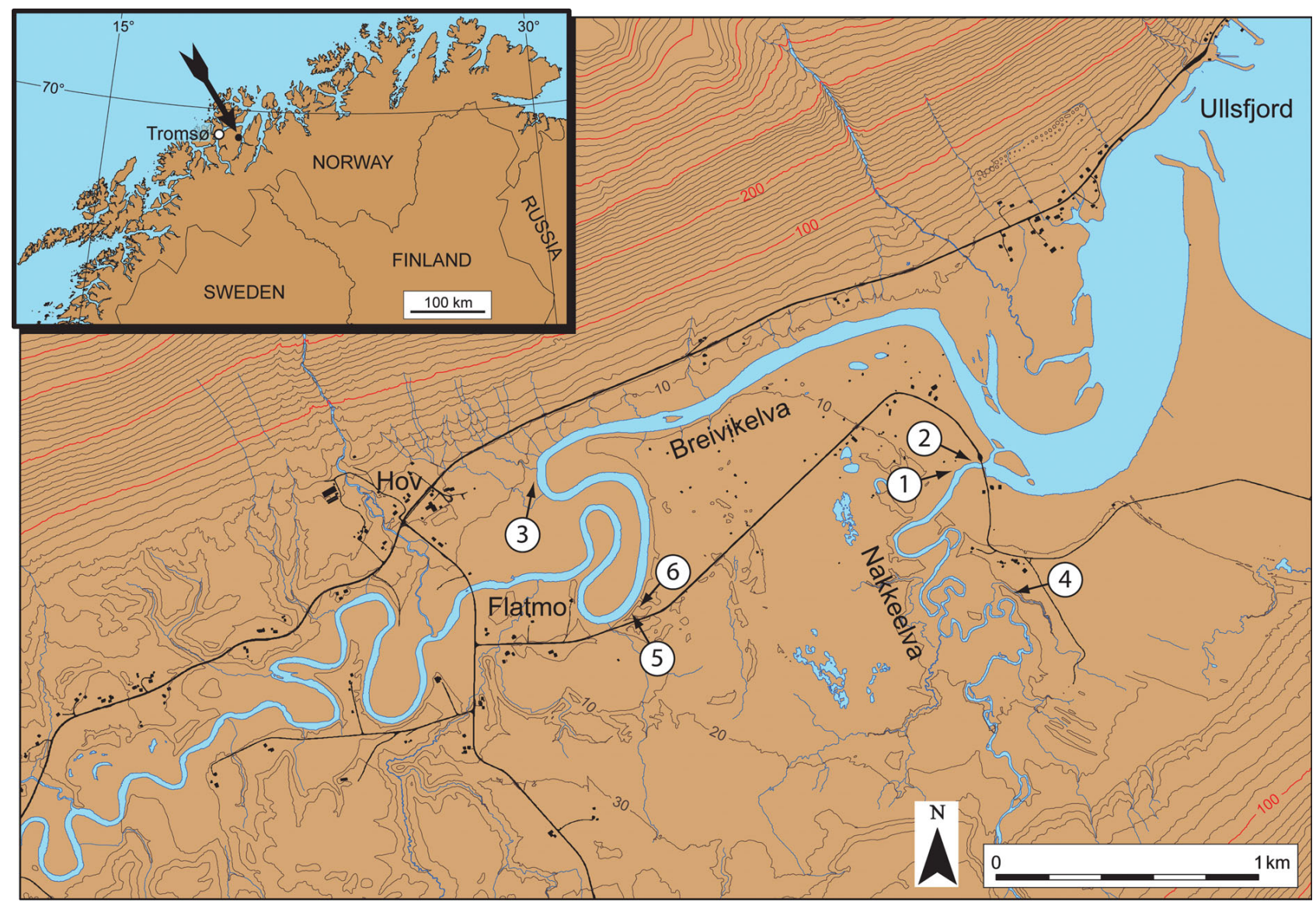

Figure 1. Topographical map of the study area in the Troms County, North Norway. The main river is Breivikelva, with its tributary Nakkeelva. Investigated localities in the Breivikeidet area are indicated by numbers. Contour lines $10 \mathrm{~m}$. Modified from Helama et al. (2014). Numbers and arrows indicate positions of the six localities studied.

macrofaunal skeletal remains are investigated in detail for the first time herein. The remains are from species that still have modern representatives of which the living conditions are well known. Close comparisons with the modern communities can provide us new knowledge about the biotic and abiotic parameters of the early Holocene fjord-deltaic system in the Breivikeidet area of Troms County.

\section{Geological setting}

\section{Previous studies}

Breivikeidet is a valley extending from the Ramfjord in southwest to the Ullsfjord in northeast (Fig. 1). Steep mountains confine Breivikeidet to the northwest, while lower and less steep mountains are present to the southeast. A marginal moraine, Ramfjordmoen, is in the southwest end of the Breivikeidet Valley (Andersen 1968, Møller et al. 1986, Dagestad et al. 2006). The valley deposits comprise mainly late Quaternary outwash plain (valley train) and fluvial and marine deposits (Holmes \& Andersen
1964, Andersen 1968). Aerial photographs of the delta plain show a mosaic of abundant distributary channels and interchannel environments dominated by flood plains and bogs. The presence of remains that represent terrestrial vegetation in these delta sediments indicates that the hinterland also was vegetated during early Holocene.

The Weichselian and Holocene sediments have been subjected to post-glacial isostatic uplift and are exposed in river sections along Breivikelva and its tributaries. Subsequent to the ice sheet had melted away from the area; the sea level was higher than its present level. Ancient shorelines and their displacement curves in Troms county have been constructed by Pettersen (1880), Marthinussen (1962), Andersen (1968), Corner (1980), Hald \& Vorren (1983), Møller (1987, 1989) and Corner \& Haugane (1993). The displacement curve nearest to Breivikeidet originates from the Lyngen area (Corner \& Haugane 1993), $15 \mathrm{~km}$ northeast of the study area, the Lyngen being characterised by slightly lower isobases than the Breivikeidet. We estimate a need of an adjustment of approximately $1 \mathrm{~m}$ for the latter. A rapid pre-Tapes regression of about $10-15 \mathrm{~mm} / \mathrm{yr}$ (before $8,500{ }^{14} \mathrm{C}$ years $\mathrm{BP}$ ) 
was followed by the Tapes transgression (Corner \& Haugane 1993). The transgression reached maximum at about $7,000{ }^{14} \mathrm{C}$ years $\mathrm{BP}$ in the Lyngen area, where the sea-level rise was at least $2-3 \mathrm{~m}$ at the time. A slow post-Tapes regression, which occurred after $6,000{ }^{14} \mathrm{C}$ years BP because of a glacio-isostatic rebound, had a rate of about 1.5-3 mm/yr (Corner \& Haugane 1993). Because of the continued rebound, the rivers proceeded to erode into older fluvial and marine deposits.

At Breivikeidet, a river section through steep-faced fjord delta deposits were previously investigated ichnologically by Corner \& Fjalstad (1993), about 750 m NNE from our locality 3 (Fig. 1). A radiocarbon date of $9,060 \pm 80$ years BP (T-6027) was determined for Macoma calcarea in bottomset beds $1 \mathrm{~m}$ above river level. Making use of regional sea-level displacement curves and shoreline diagrams, Corner \& Fjalstad (1993) interpreted the sea level to have been $30-35 \mathrm{~m}$ higher than its present level and, therefore, the depositional water depth of the bottomsets having been approximately $30 \mathrm{~m}$.

Ground penetrating radar (GPR) profiles and two wells penetrating the sediments at the Hov waterworks (Hilmo 2011) are located approximately $500 \mathrm{~m}$ west from our locality 3 (Fig. 1). An upper unit of dipping layers comprises sand, gravel and stones was identified, overlaying the lower unit of horizontally layered mud, the unit transition found 5-12 m below the ground level (Hilmo 2011). The GPR measurements were unable to map the total sediment thickness that reach at least $70 \mathrm{~m}$ in the middle of the valley (Hilmo 2011). Building on Corner \& Fjalstad's (1993) data, the coarse-grained unit is probably fjord-delta foresets and topsets, while the mud unit represents prodelta deposits.

\section{Studied localities}

The six localities of this study are all river sections along Breivikelva and its tributary Nakkeelva (Fig. 1), positioned at $69.65663^{\circ} \mathrm{N}, 19.62355^{\circ} \mathrm{E}$ (locality 1$) ; 69.65664^{\circ} \mathrm{N}$, $19.62430^{\circ} \mathrm{E}$ (locality 2); $69.65700^{\circ} \mathrm{N}, 19.58086^{\circ} \mathrm{E}$ (locality 3 ); $69.65204^{\circ} \mathrm{N}, 19.62648^{\circ} \mathrm{E}$ (locality 4$) ; 69.65229^{\circ} \mathrm{N}$, $19.58889^{\circ} \mathrm{E}$ (locality 5); and $69.65257^{\circ} \mathrm{N}, 19.58963^{\circ} \mathrm{E}$ (locality 6); based on the Norwegian Mapping Authority (http://www.norgeskart.no/).

\section{Sedimentological description}

The sedimentary successions of these localities show a spatial complexity in their architecture of bottomsets, foresets and topsets (Figs 2-6). The bottomsets, which are gently inclined (less than $10^{\circ}$ ), are well exposed in our localities 1 , 2 and 3 . The bottomsets are characterised by massive, bioturbated or laminated mud, which may be interbedded by
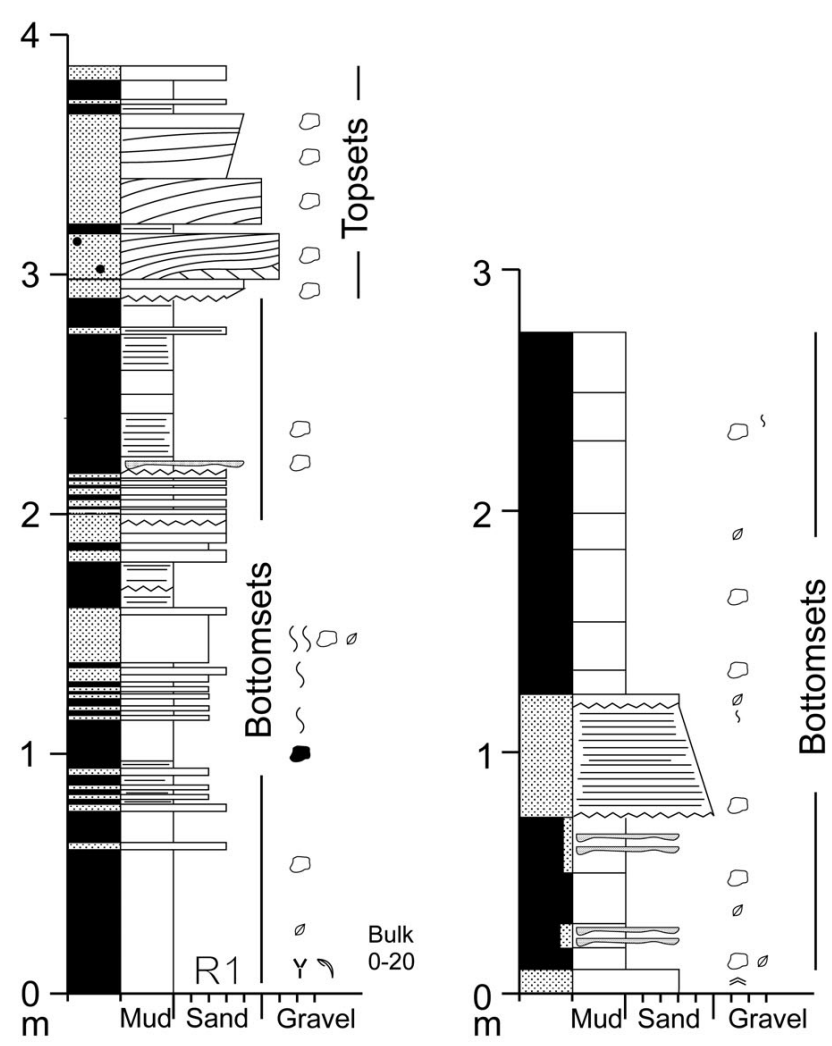

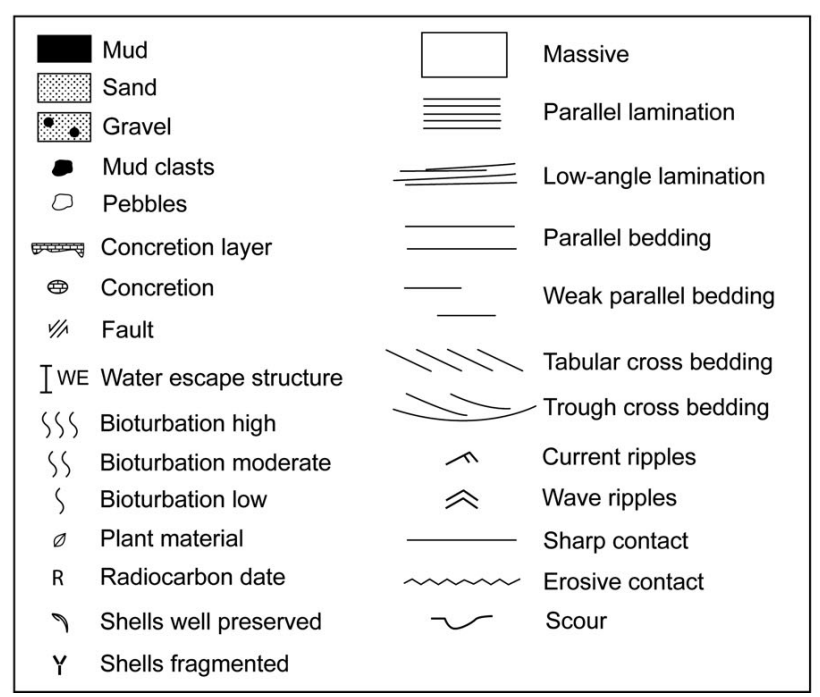

Figure 2. Sedimentological logs of the localities 1 and 2 showing the stratigraphical positions of bulk sediment samples and radiocarbon sample. Measured from $0.5 \mathrm{~m}$ above mean sea level.

thin sandy beds (e.g. locality 6). The sand is up to medium in grain size. The bottomsets are characterised by vertical transition into foresets (e.g. locality 5) or topsets (locality 3). The foresets are well exposed in our localities 4,5 and 6 . The foresets are dipping up to $15^{\circ}$ and generally more coarse-grained than the bottomsets. Bed thickness in the foresets is up to more than $2 \mathrm{~m}$. Massive beds are sandy 

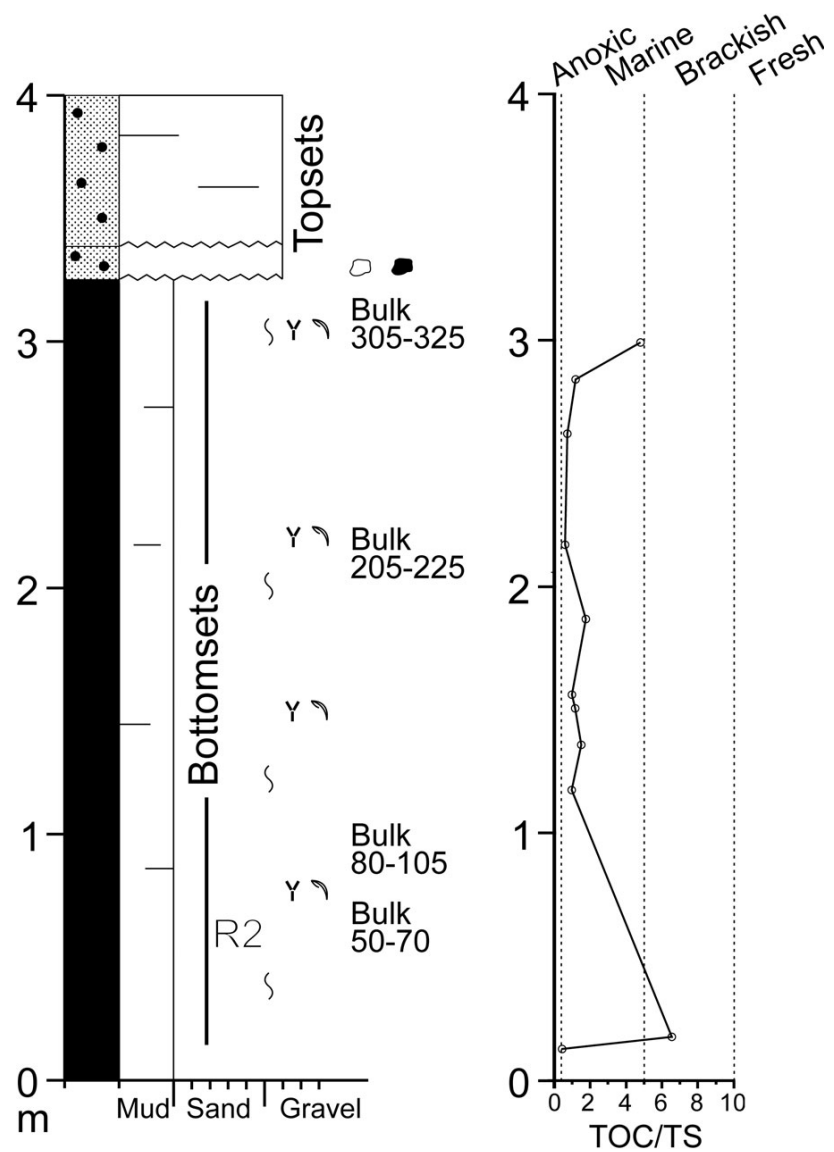

Figure 3. Sedimentological $\log$ of the locality 3 showing the stratigraphical positions of bulk sediment samples and radiocarbon sample. Measured from $1 \mathrm{~m}$ above mean sea level. Modified from Helama et al. (2014).

to gravely (e.g. localities 4 and 5). Parallel to low angle lamination in beds of silt to medium sand are characteristic to locality 5, in particular. Current ripples and scours are also present in the foresets. The foresets are unconformably truncated by nearly horizontal topsets characterised by coarse-grained sediment, typically sand to fine gravel. There are massive beds and beds with trough crossbedding with garnet sand, parallel to low angle lamination and current ripples (e.g. localities 4, 5 and 6).

\section{Sedimentary environment}

The sediments make up bottomsets, foresets and topsets well known from deltas (e.g. Scruton 1960). The bottomset mud was deposited predominantly by suspension fallout on a low-angle prodelta. The thin sandy beds may have originated from high-energy sediment gravity flows. Gently dipping bottomsets and steeper foresets are known from steep-faced fjord deltas in North Norway (Corner et al. 1990, Corner \& Fjalstad 1993, Eilertsen et al. 2011). Depositional processes of bottomsets on such fjord deltas may have been down into
$44.5 \mathrm{~m}$ deep water and possibly deeper (Eilertsen et al. 2011). As an analogue for the deltaic setting, we have used the nearby locality of Corner \& Fjalstad (1993).

The foresets were mainly formed by cohesion-less debris flows (grain flows). The current ripples and scours indicate traction currents. Depositional processes forming the foresets were most likely initiated by storms and tide causing mixing of the water column. Submarine channelized sand is recognised in locality $5 \mathrm{SW}(710-1105 \mathrm{~cm}$; Fig. 5), indicating genetic complexity of the foresets. Lateral shift away of a distributary channel can be represented by the fine-grained interval below $(565-710 \mathrm{~cm})$. Some beds within the foresets of locality $5 \mathrm{NE}$ (Fig. 5) have been deformed by liquefaction and show related slumping and sliding. The topsets are characterised by coarse-grained sediment and trough to planar cross-bedding, related to fluvial bedload. The topsets unconformably truncating the foreset beds are also known from the locality of Corner \& Fjalstad (1993).

Continued sediment supply from Breivikelva River has resulted in a shoreline progradation producing the fjord-head delta. The shoreline has prograded since early Holocene, with the coarser material being deposited near the river mouth while the finer sediments are transported further away and being deposited from suspension as bottomsets and offshore sediments.

\section{Material and methods}

Field observations and bulk samples form the basis for the present study of the fossil macrofauna (Tab. 1). Bulk samples of 10 litres were dried before being gently washed through a set of sieves of $1-2,2-4,4-8,8-16$, and > $16 \mathrm{~mm}$. Where the sediment contained little shell material, additional 10 litres of sediment were taken and processed (bulk sample $0-25 \mathrm{~cm}$ in locality 4 ). Sediment retained on the sieve was dried, shell material was hand-picked and examined from each size fractions. The number of valves and fragments was counted. The following bulk samples did not contain identifiable shell material: $477-504 \mathrm{~cm}$, 548-567, 625-645, 1103-1130, 1260-1278, 1380-1410, 1469-1487 (locality 4), 1000-1015 (locality 6). These were not processed further.

Well preserved valves were sent for accelerator mass spectrometry (AMS) radiocarbon dating. The dates R1, R3, R4, R5, R6 and R7 are based on single valves of Macoma calcarea, whereas R8 and R9 were derived from multiple valves of the same species (Tab. 2). The dates $\mathrm{R} 2 \mathrm{a}-\mathrm{e}$ represent single valves of Arctica islandica from locality 3 (Helama et al. 2014). A set of Arctica islandica shells from locality 3 was previously analysed for their concentration of uranium, but the levels were insufficient to be exploited in U-series dating (Helama et al. 2015). As 


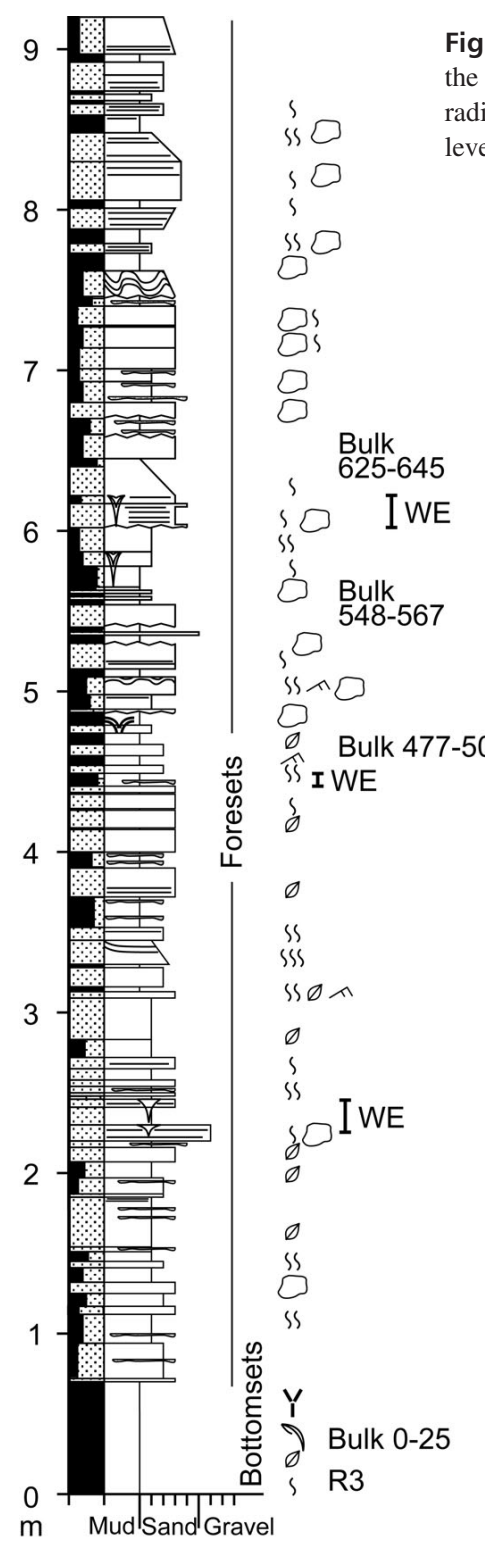

Figure 4. Sedimentological log of the locality 4 showing the stratigraphical positions of bulk sediment samples and radiocarbon sample. Measured from $1.5 \mathrm{~m}$ above mean sea level.

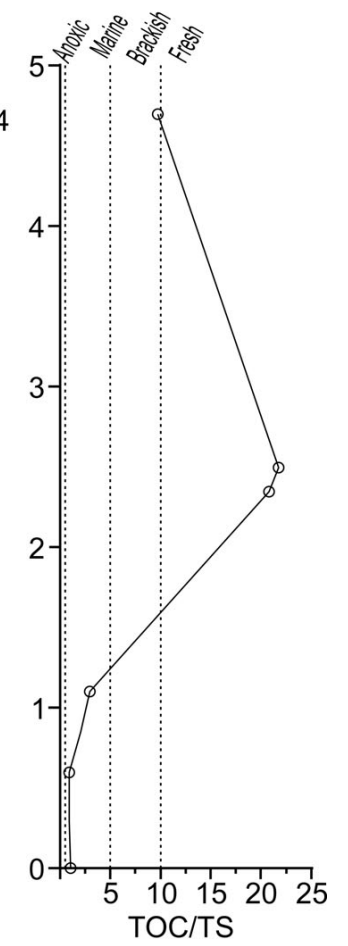

a result, the ${ }^{14} \mathrm{C}$ method appeared the most accurate method for dating this shell material. The calculation programme OxCal version 4.2 (2013) by Bronk Ramsey (2009) was applied together with the calibration curve Marine13 from Reimer et al. (2013). The radiocarbon dates were corrected for local reservoir effect by using the Marine Reservoir Correction Database (http://radiocarbon.pa.qub.ac.uk/), $\Delta \mathrm{R} 65 \pm 37$ years based on the T-1534 date of the suspension-feeding bivalve Chlamys islandica (Mangerud \& Gulliksen 1975; see Craig 1954, Mangerud 1972, Mangerud et al. 2006). The fjord delta succession locally contains terrestrial plant remains, which suggests that the waters during deposition contained some old carbon. Feeding bivalves may have incorporated old carbon into the shells and this could result in somewhat older dates

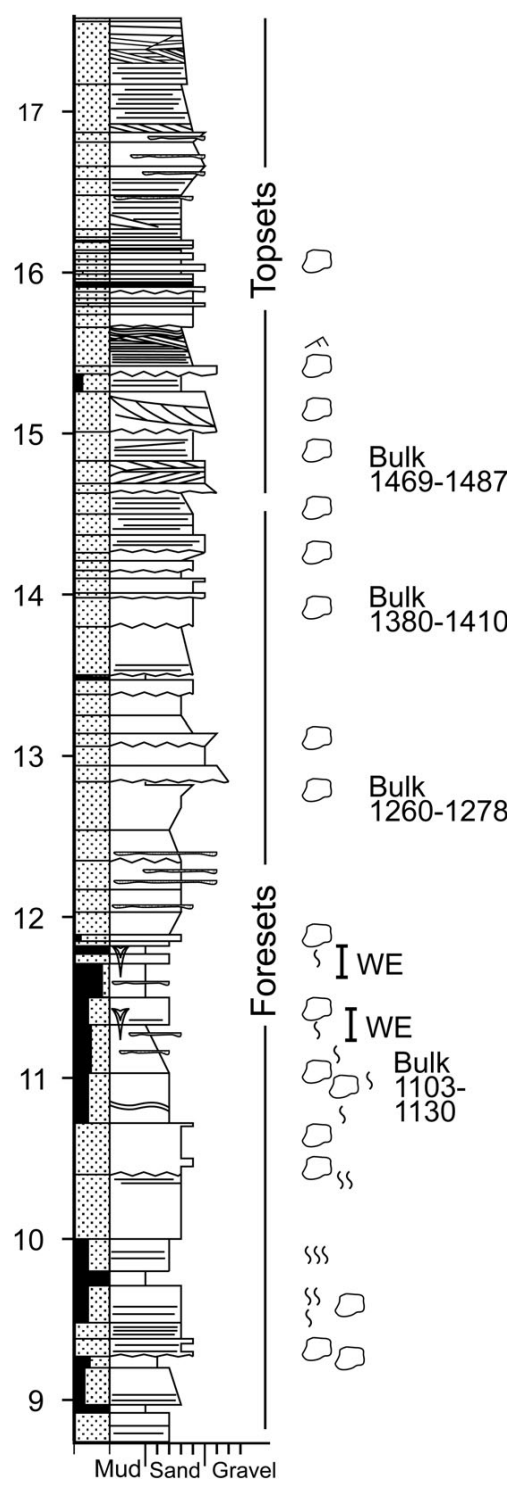

(Mangerud et al. 2006). Radiocarbon dates herein are from both suspension-feeders (Arctica islandica) and surface deposit-feeders (Macoma calcarea); the latter appears more likely to yield older ages of which we, however, have no evidence. Calendar ages are in Gregorian years before mid AD 1950.

Individual shell pieces were scored by visualising them for the taphonomical features of abrasion, bioerosion, disarticulation, dissolution, encrustation and fragmentation to assess their preservation. For this, the three-level scheme of taphonomical grades by Kowalewski et al. (1995) was used. The grades with 0, 1 and 2 levels refer to none, low and high alteration, respectively. Grade 2 means that more than $20 \%$ shell surface has been altered, with an exception of $50 \%$, for fragmentation. 


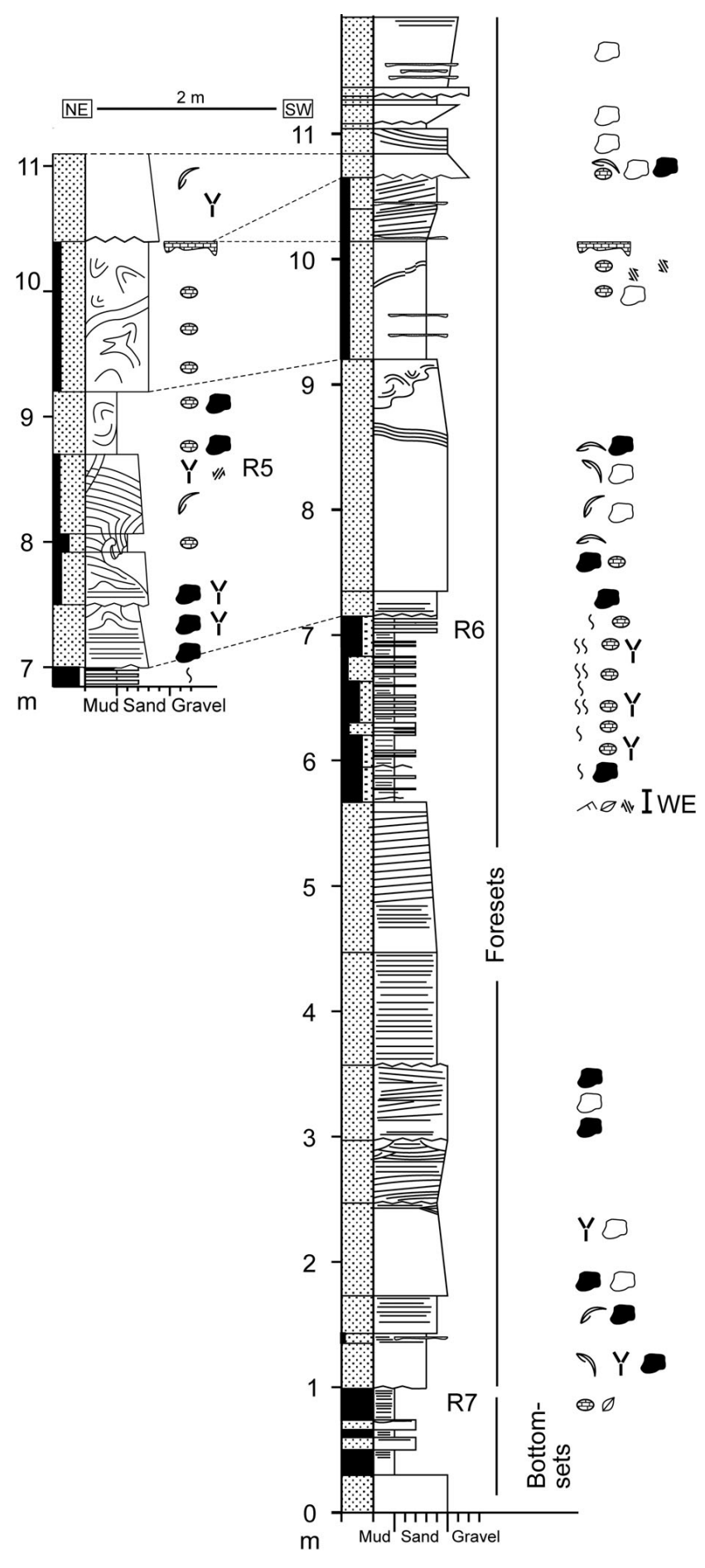

Twenty-eight samples from silty clay in the localities 3 , 4 and 5 (Figs 3-5) were analysed for contents of total carbon (TC), total sulphur (TS) and total organic carbon (TOC), for indications of bottom water oxygenation and salinity during deposition (Berner \& Raiswell 1984, Leventhal 1995, Morse \& Berner 1995). The samples were dried at $40{ }^{\circ} \mathrm{C}$, crushed to fine powder, and dried at $65^{\circ} \mathrm{C}$

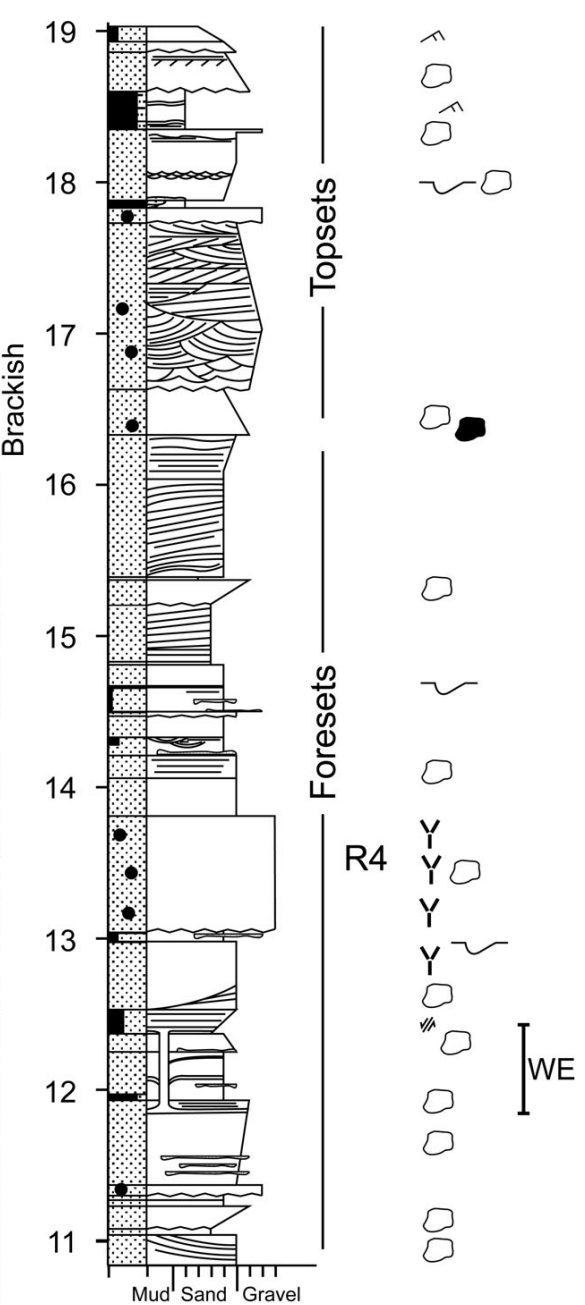

Figure 5. Sedimentological log of the locality 5 showing the stratigraphical positions of bulk sediment samples and radiocarbon samples. Measured from $3 \mathrm{~m}$ above mean sea level.

for a minimum of 12 hours. An amount of 0.3-0.4 $\mathrm{g}$ of crushed sample was usually used, while the weight of shell-rich samples was increased to $0.6 \mathrm{~g}$ for TOC analyses, in order to compensate for weight lost during double acidic treatment with $3 \mathrm{ml}$ warm $2 \mathrm{M} \mathrm{HCl}$. Prior to analysis, the samples were rinsed repeatedly with distilled water to remove any acid remains and $\mathrm{CaCl}_{2}$ formed during the acid 
treatment. The instrument LECO CS-200 was calibrated against LECO standards, blank samples and the international standard 501-506 STD. Also the international standard LKSD-1 consisting of lake sediments from Joe Lake and Brady Lake, Ontario, USA, was used (Lynch 1990). The instrumental precision is $2 \mathrm{ppm}$ or $0.5 \%$ standard deviation for carbon, and $2 \mathrm{ppm}$ or $1.5 \%$ for sulphur, or what is largest.

\section{Results}

\section{Fossil macrofauna}

Molluscs and barnacles were determined after the literature cited elsewhere herein, in addition to Petersen (2001), Petersen (2004) and Darwin (1854b). The macrofauna comprises particularly shell remains of bivalves (Tab. 1). Barnacles and gastropods are less common, and remains of regular sea urchins are rare.

The shell abundance and diversity are moderate to high in the fine-grained intervals of the bottomsets (Tab. 1). Shells of Macoma calcarea are common or even abundant in the bottomsets and fine-grained foresets. Mya truncata is also present in the samples, albeit in smaller amount. We acknowledge the long-lasted discussion on $M$. truncata shell morphology, to distinguish possible forms and species (e.g. Jensen 1901, Jensen \& Spärck 1934, Petersen 1999), and note that most of our shells are of similar form to recent specimens of $M$. truncata, characteristic of the European boreal province; for example, $M$. truncata forma typica and M. truncata as described by Jensen (1901) and Petersen (1999), respectively. Some of the large valves from locality $3(80-105 \mathrm{~cm})$ show a morphological continuum towards a shorter pallial sinus. We also note that the juvenile valves from the study area have a larger posterior end that is less truncated than observed in the adults (see Jensen 1901, Oliver et al. 2016).

Abra nitida and Abra sp. are common in samples from the fine-grained intervals of bottomsets (Tab. 1). We concur with Jensen \& Spärck (1934) who found small specimens of Abra nitida to be hardly differentiated from another species, Abra alba. As a consequence, these specimens have here been assigned to Abra sp. Arctica islandica, cardiid indet. and Mytilus edulis are other major taxa to occur in our samples (Tab. 1). The shell preservation is generally good in the fine-grained sediments, where articulated shells and skeletal parts may be present with periostracum and ligament (Figs 7-9). Both small and large shells of bivalves are present.

At locality $3(80-105 \mathrm{~cm})$, the bottomsets contain several valves of Arctica islandica, Astarte elliptica, Hiatella arctica, Mya truncata, Mytilus edulis and Panomya norvegica, which are articulated and large in size. There are also incredibly well preserved, large valves of Chlamys

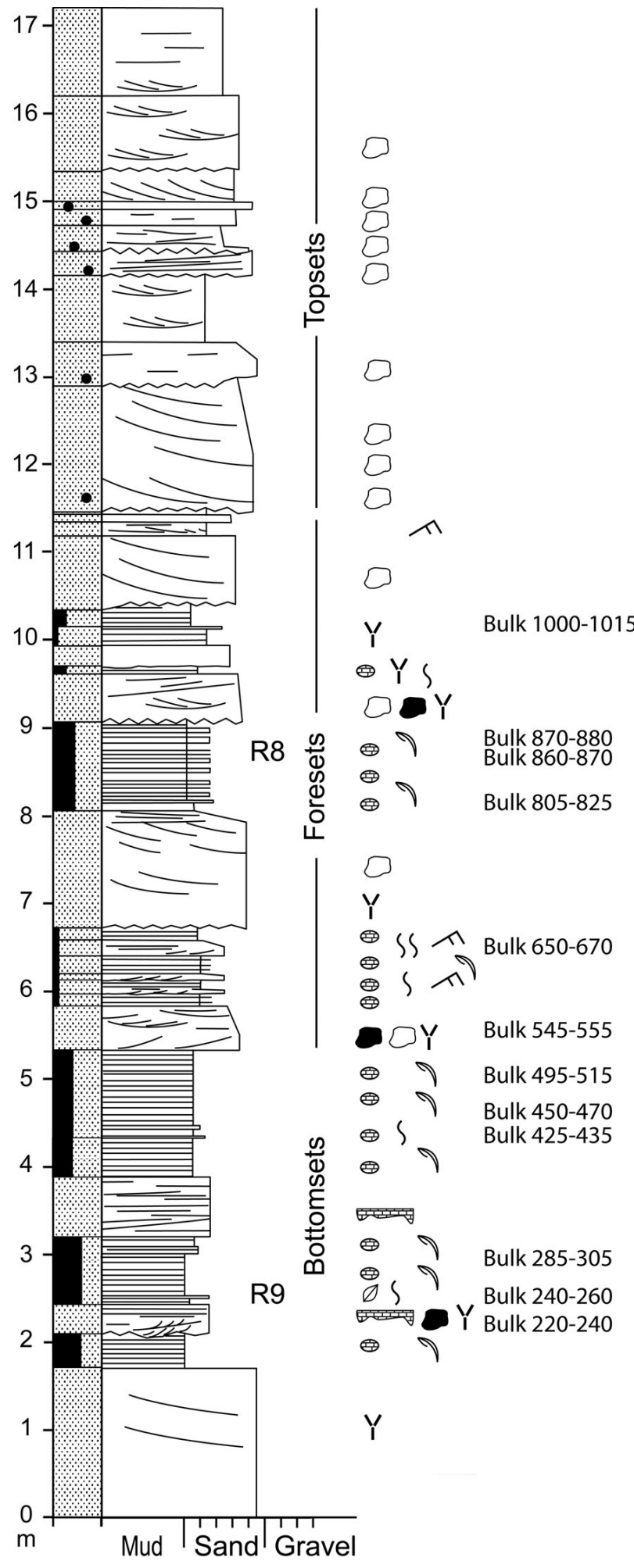

Figure 6. Sedimentological log of the locality 6 showing the stratigraphical positions of bulk sediment samples and radiocarbon samples. Measured from $1 \mathrm{~m}$ above mean sea level. 
Table 1. Invertebrate macrofossils in the examined bulk samples. Numbers indicate the amount of individual valves. Numbers in brackets are for fragments.

\begin{tabular}{|c|c|c|c|c|c|c|c|c|c|}
\hline Locality & Loc. 1 & Loc. 3 & Loc. 3 & Loc. 3 & Loc. 3 & Loc. 3 & Loc. 4 & Loc. 6 & Loc. 6 \\
\hline Level $(\mathrm{cm})$ & $0-20$ & $50-70$ & $80-105$ & H80-105 & $205-225$ & $305-325$ & $0-25$ & $220-240$ & $240-260$ \\
\hline \multicolumn{10}{|l|}{ GASTROPODA } \\
\hline Boreotrophon clathratus (Linnaeus, 1767) & - & - & $2(3)$ & 1 & - & - & - & - & - \\
\hline Buccinum undatum Linnaeus, 1758 & - & - & - & 2 & - & - & - & - & - \\
\hline Cylichna sp. & $2(1)$ & - & 2 & - & 3 & - & - & - & - \\
\hline Lepeta caeca (Müller, 1776) & - & - & 1 & - & - & - & - & - & - \\
\hline Littorina littorea (Linnaeus, 1758) & - & - & - & - & - & - & (1) & (2) & - \\
\hline Littorinid indet. & - & - & 2 & - & - & - & $1(1)$ & - & - \\
\hline Nassariid indet. & - & - & (1) & - & - & - & - & - & - \\
\hline Naticid indet. & 1 & - & (1) & 2 & - & - & 1 & - & - \\
\hline Neptunea despecta (Linnaeus, 1758) & - & - & - & 4 & - & - & - & - & - \\
\hline Turrid indet. & - & - & 1 & - & - & - & - & - & - \\
\hline \multicolumn{10}{|l|}{ BIVALVIA } \\
\hline Abra nitida (Müller, 1776) & - & - & 12 & 2 & 29 & 2 & - & 2 & 2 \\
\hline Abra sp. & - & 6 & $17(3)$ & - & $19(3)$ & 3 & - & - & - \\
\hline Acanthocardia echinata (Linnaeus, 1758) & - & - & $1(4)$ & - & $? 1$ & - & - & - & $3(8)$ \\
\hline Anomiid indet. & - & - & 6 & 2 & - & - & - & - & - \\
\hline Arctica islandica (Linnaeus, 1767) & 1 & - & $42(31)$ & $13(2)$ & - & - & $3(1)$ & - & - \\
\hline Astarte borealis (Schumacher, 1817) & - & - & $4(3)$ & - & - & - & - & - & - \\
\hline Astarte elliptica (Brown, 1827) & - & - & $16(23)$ & 2 & - & - & - & - & - \\
\hline Astarte sp. & (1) & - & $3(2)$ & - & - & - & - & - & - \\
\hline Axinopsida orbiculata (Sars, 1878) & 2 & - & 2 & - & 1 & - & $4(2)$ & - & - \\
\hline Cardiid indet. & $3(7)$ & $2(1)$ & $16(48)$ & - & 1 & - & $4(20)$ & - & $1(2)$ \\
\hline Cerastoderma edule (Linnaeus, 1758) & 3 & - & $11(2)$ & 1 & $1(1)$ & - & - & - & 2 \\
\hline Chlamys islandica (Müller, 1776) & - & - & $1(4)$ & $29(4)$ & - & - & - & - & - \\
\hline Crenella decussata (Montagu, 1808) & 2 & - & $138(102)$ & 4 & - & 1 & $9(1)$ & - & - \\
\hline Hiatella arctica (Linnaeus, 1758) & - & - & $15(16)$ & 6 & - & - & - & - & - \\
\hline Macoma balthica (Linnaeus, 1758) & - & - & - & - & - & - & - & - & - \\
\hline Macoma calcarea (Gmelin, 1791) & $65(25)$ & $42(13)$ & $578(259)$ & $45(7)$ & $92(20)$ & $33(12)$ & $136(83)$ & $7(6)$ & $68(84)$ \\
\hline Mya truncata Linnaeus, 1758 & $7(4)$ & 3 & $52(87)$ & $36(3)$ & $9(1)$ & $1(3)$ & $42(12)$ & - & $5(9)$ \\
\hline Mytilus edulis Linnaeus, 1758 & $1(2)$ & - & $2(78)$ & 2 & $(10)$ & (3) & - & - & - \\
\hline Nucula sp. & 1 & 2 & 1 & - & $1(1)$ & - & - & - & (1) \\
\hline Nuculana pernula (Müller, 1779) & - & - & $24(23)$ & - & 2 & - & - & - & - \\
\hline Panomya norvegica (Spengler, 1793) & - & - & - & 3 & - & - & - & - & - \\
\hline Parvicardium exiguum (Gmelin, 1791) & - & - & - & - & - & - & - & - & 2 \\
\hline Parvicardium minimum (Philippi, 1836) & - & - & - & - & - & - & - & - & - \\
\hline Pectinid indet. & - & - & - & - & - & - & - & - & - \\
\hline Phaxas pellucidus (Pennant, 1777) & - & - & - & - & - & - & - & - & - \\
\hline Similipecten greenlandicus (Sowerby II, 1842) & - & - & - & - & - & - & - & $1(5)$ & - \\
\hline Thyasira sarsii (Philippi, 1845) & $2(1)$ & 2 & - & - & $1(1)$ & $1(1)$ & $11(4)$ & - & - \\
\hline Yoldiella lenticula (Möller, 1842) & 11 & 3 & $12(6)$ & - & - & 2 & 3 & 1 & - \\
\hline \multicolumn{10}{|l|}{ CIRRIPEDIA } \\
\hline Balanus balanus (Linnaeus, 1758) & - & - & $16(7)$ & $54(7)$ & - & - & - & - & - \\
\hline Balanus crenatus Bruguière, 1789 & - & - & $6(3)$ & - & - & - & - & $(2)$ & - \\
\hline Balanus sp. & - & - & $3(27)$ & - & - & - & - & (17) & - \\
\hline Verruca stroemia (Müller, 1776) & - & - & - & - & - & - & - & - & - \\
\hline
\end{tabular}

\section{ASSORTED}

Brown tubes indet.

Sea urchin skeletal parts indet. 
Table 1. continued.

\begin{tabular}{|c|c|c|c|c|c|c|c|c|c|}
\hline Locality & Loc. 6 & Loc. 6 & Loc. 6 & Loc. 6 & Loc. 6 & Loc. 6 & Loc. 6 & Loc. 6 & Loc. 6 \\
\hline Level $(\mathrm{cm})$ & $285-305$ & $425-435$ & $450-470$ & $495-515$ & $545-555$ & $650-670$ & $805-825$ & $860-870$ & $870-880$ \\
\hline \multicolumn{10}{|l|}{ GASTROPODA } \\
\hline Boreotrophon clathratus (Linnaeus, 1767) & - & - & - & - & - & - & - & - & - \\
\hline Buccinum undatum Linnaeus, 1758 & - & - & - & - & - & - & - & - & - \\
\hline Cylichna sp. & - & - & - & - & - & - & - & - & - \\
\hline Lepeta caeca (Müller, 1776) & - & - & - & - & - & - & - & - & - \\
\hline Littorina littorea (Linnaeus, 1758) & - & 2 & - & - & - & $7(4)$ & $3(14)$ & $(8)$ & - \\
\hline Littorinid indet. & $3(8)$ & - & - & - & - & - & - & - & - \\
\hline Nassariid indet. & - & - & - & - & - & - & - & - & - \\
\hline Naticid indet. & - & - & - & - & - & - & - & - & - \\
\hline Neptunea despecta (Linnaeus, 1758) & - & - & - & - & - & - & - & (1) & - \\
\hline Turrid indet. & - & - & - & - & - & - & - & - & - \\
\hline \multicolumn{10}{|l|}{ BIVALVIA } \\
\hline Abra nitida (Müller, 1776) & 3 & $1(2)$ & (15) & - & - & - & - & - & - \\
\hline Abra sp. & - & - & - & - & - & - & - & - & - \\
\hline Acanthocardia echinata (Linnaeus, 1758) & - & $1(8)$ & 1 & - & - & - & - & - & - \\
\hline Anomiid indet. & - & - & - & - & - & - & - & - & - \\
\hline Arctica islandica (Linnaeus, 1767) & - & - & - & - & - & - & - & - & - \\
\hline Astarte borealis (Schumacher, 1817) & - & - & - & - & - & - & - & - & - \\
\hline Astarte elliptica (Brown, 1827) & - & - & - & - & - & - & - & - & - \\
\hline Astarte sp. & - & - & - & - & - & - & - & - & - \\
\hline Axinopsida orbiculata (Sars, 1878) & - & - & - & - & - & - & - & - & - \\
\hline Cardiid indet. & - & 4 & 5 & - & $1(11)$ & - & - & 2 & 1 \\
\hline Cerastoderma edule (Linnaeus, 1758) & - & 3 & - & - & $1(3)$ & - & - & (7) & $3(9)$ \\
\hline Chlamys islandica (Müller, 1776) & - & - & - & - & - & - & - & - & - \\
\hline Crenella decussata (Montagu, 1808) & - & - & - & - & - & - & - & - & - \\
\hline Hiatella arctica (Linnaeus, 1758) & - & - & - & - & - & - & - & - & - \\
\hline Macoma balthica (Linnaeus, 1758) & - & - & $8(1)$ & - & - & - & 2 & $1(1)$ & $1(2)$ \\
\hline Macoma calcarea (Gmelin, 1791) & $2(4)$ & $47(102)$ & $129(101)$ & (2) & (11) & (1) & (10) & - & $4(20)$ \\
\hline Mya truncata Linnaeus, 1758 & $1(1)$ & $26(37)$ & $42(79)$ & $2(1)$ & $2(46)$ & - & (9) & - & $1(10)$ \\
\hline Mytilus edulis Linnaeus, 1758 & (3) & $2(12)$ & 1 & - & - & (33) & (148) & (12) & (2) \\
\hline Nucula sp. & - & $1 ?$ & - & - & - & - & - & - & - \\
\hline Nuculana pernula (Müller, 1779) & - & - & 2 & - & - & - & - & - & - \\
\hline Panomya norvegica (Spengler, 1793) & - & - & - & - & - & - & - & - & - \\
\hline Parvicardium exiguum (Gmelin, 1791) & - & - & - & - & - & - & - & - & - \\
\hline Parvicardium minimum (Philippi, 1836) & - & (2) & - & - & - & - & - & - & - \\
\hline Pectinid indet. & - & - & - & - & - & - & 2 & - & 1 \\
\hline Phaxas pellucidus (Pennant, 1777) & - & - & 1 & - & - & - & - & - & - \\
\hline Similipecten greenlandicus (Sowerby II, 1842) & (4) & 1 & - & - & - & - & - & - & - \\
\hline Thyasira sarsii (Philippi, 1845) & $2 ?$ & - & - & - & - & - & - & - & - \\
\hline Yoldiella lenticula (Möller, 1842) & $4(9)$ & 1 & - & - & - & - & - & - & - \\
\hline \multicolumn{10}{|l|}{ CIRRIPEDIA } \\
\hline Balanus balanus (Linnaeus, 1758) & - & - & - & - & - & 1 & - & 1 & - \\
\hline Balanus crenatus Bruguière, 1789 & (2) & - & 1 & - & - & 7 & $4(4)$ & 2 & - \\
\hline Balanus sp. & $2(23)$ & 2 & 2 & (2) & $3(8)$ & 4 & $2(9)$ & (12) & 2 \\
\hline Verruca stroemia (Müller, 1776) & - & - & 1 & - & - & - & - & $(5)$ & - \\
\hline \multicolumn{10}{|l|}{ ASSORTED } \\
\hline Brown tubes indet. & 1 & - & - & - & - & 4 & 2 & - & - \\
\hline Sea urchin skeletal parts indet. & - & - & 2 & - & - & - & - & - & - \\
\hline
\end{tabular}


islandica onto which Balanus balanus, an acorn barnacle, may occur abundantly. The presence of this barnacle is evident only on outer shell surfaces, indicating encrustation while the bivalves were alive. Specimens of B. balanus rarely contain Hiatella arctica that lived inside them. The same interval holds some large shells of Buccinum undatum and Neptunea despecta.

The coarse-grained intervals of the foresets are characterised by much lower quantity and diversity of shells. Shell fragments are scarce and most of them are unidentifiable. Macoma calcarea, M. balthica and cardiid indet. have been found. Field observations showed that the shell material in the coarse-grained foresets at the localities 5 and 6 is considerably more fragmented than in bottomsets and fine-grained foresets (Fig. 9). The shell material is characterised by various grades of dissolution. Mytilus edulis is particularly affected by fragmentation and dissolution, and the shells from the coarse-grained foresets are commonly preserved as loosely attached fibrous prisms from the calcite shell layer, purple in colour (see Nielsen 2004). Some of the prisms may originate from another mytilid, Modiolus modiolus (see Anwar et al. 1990); however, all identified fragments indicate Mytilus edulis. Irregular flakes of aragonitic nacre are rare and might derive from Mytilus edulis. Cardiid indet. and fragments of unidentifiable specimens occur sporadically and differ from those of Mytilus edulis by their chalky appearance that results from dissolution.

Contrary to the bottomsets and foresets, the topsets are barren of macrofaunal fossils.

\section{Radiocarbon dates}

Radiocarbon dating of shell material assigned to Macoma calcarea gave eight calibrated ages (Tab. 2). The youngest mean ages are 6,374 and 6,406 years cal BP in the lowermost part (bottomsets) of the localities 1 and 4, respectively (Figs 2,4). The confidence ranges of these dates of Atlantic time overlap with each other. The other ages are at least 4,000 years older. Five valves of Arctica islandica from the bottomsets in the lower part of locality 3 gave a mean of 10,878 to 11,005 years cal BP, indicating Preboreal (Tab. 2; Helama et al. 2014).

Four dates are available for the locality 5 . The date R7 is 10,440 years cal BP (Preboreal) for bottomsets in the lowest part of the succession. The dates R6, R5 and R4 are from different levels in the overlying foresets. R6 is 10,606 years cal BP (Preboreal). R5 and R4 are 13,167 and 11,779 years cal BP indicating Allerød and Younger Dryas, respectively. Considering their confidence ranges (Tab. 2), they are stratigraphically inconsistent with the dates R7 and R6 sampled from deeper levels. From locality 6 , R9 and R8 show ages of 10,580 and 10,734 years cal BP.
The confidence ranges overlap partially each other with consistent indication of Preboreal time.

\section{LECO values}

At locality 3, the TOC values of 11 samples range from 0.092 to 0.172 weight $\%$ (Figs 3, 10A, Tab. 3). The TS values are between 0.014 and 0.606 weight $\%$. The stratigraphical trends in the values are generally smooth. However, the TS value from the stratigraphical level $12 \mathrm{~cm}$ is much higher than at the other sampled levels. At locality 4, the eight geochemical samples were taken from the sparse occurrence of clay-rich layers suitable for LECO analysis (Fig. 10B, Tab. 3). The TOC values are between 0.109 and 0.702 weight $\%$, while the TS values range from 0.008 to 0.766 weight $\%$. Stratigraphically, the trends in TOC and TS values resemble each other, decreasing upwards in the succession (Figs 4, 10B). At locality 5 (Fig. 10C), the TOC values vary between 0.091 and 0.15 weight $\%$, and the TS values between 0.068 and 0.126 weight $\%$, the TOC and TS values thus following each other through the section (Figs 5, 10C, Tab. 3).

\section{Discussion}

\section{Shell preservation}

Overall, the succession is coarsening upwards due to shallowing during the delta progradation into the fjord. The higher hydrodynamical energy during the shallowing time can thus explain the parallel trend towards poorer shell preservation (Fig. 9). The transportation of shell material caused mechanical destruction depending on the mechanism and the hydrodynamical energy level, in relation to shell morphology and microstructural strength (e.g. Nielsen 2004). Seaward transport of shells, wrack (Fucus), gravel and pebbles away from the shore is a process evident for the recent fjord system of Troms County (Kiær 1902, 1908). Dredging the deep parts of the fjords reveals mud with shells derived from shallower waters (e.g. Mytilus edulis, Cerastoderma edule), and large quantities of wrack with shallow-water animals (Kiær 1908). This transport is by wave activity and the strong tidal current that regularly occurs through the fjords (Kiær 1908). This is also the case for the present Ullsfjord off Breivikeidet. Incorporation of material into ice flakes, which drift out onto the fjords and melt, is another transport mechanism (Kiær 1902). Similar transport processes plausibly existed in the study area during early Holocene.

Reworking and associated time-averaging (e.g. Kidwell \& Bosence 1991, Flessa \& Kowalewski 1994) are evident from radiocarbon dates indicating older shells 


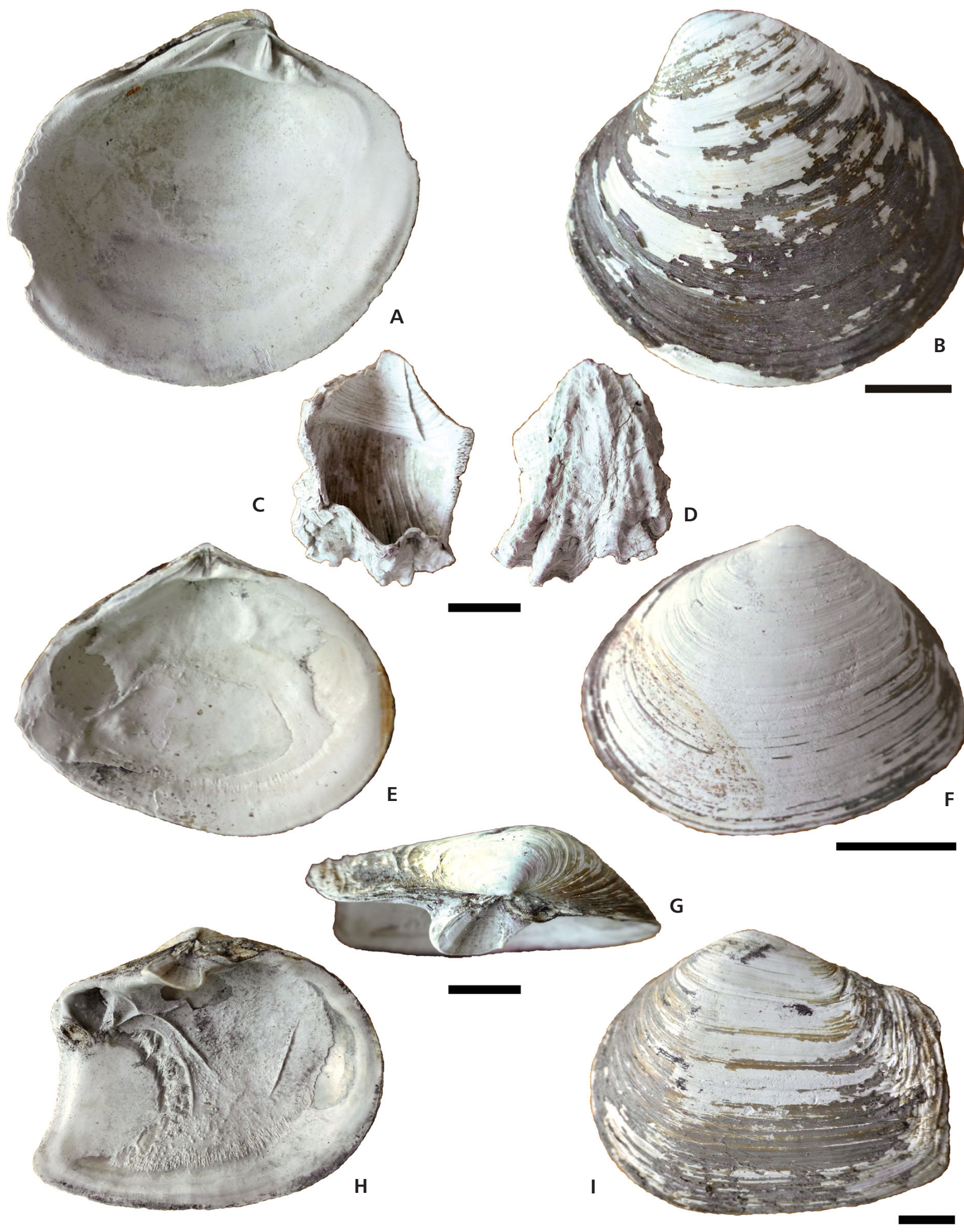

Figure 7. Common species of bivalves, barnacles and gastropods from locality 3 (sample H80-105 cm). Inner and outer shell surfaces of valves. - A, B - Arctica islandica (Linnaeus, 1767). C, D - Balanus balanus (Linnaeus, 1758). E, F-Macoma calcarea (Gmelin, 1791). $\bullet$ G-I-Mya truncata, Linnaeus, 1758. Scale bar $10 \mathrm{~mm}$. 
Table 2. Radiocarbon dates of shell material. Abbreviations: (1) = The Institute of Physics, Silesian University of Technology, Poland (laboratory report 18/2012); (2) = Poznań Radiocarbon Laboratory, Poland (laboratory report 4732/10); (3) = The ${ }^{14}$ C Dating Centre, Department of Physics and Astronomy, University of Aarhus, Denmark (2001); (4) = Radiological Dating Laboratory, Norwegian Institute of Technology, Trondheim (Nydal 1960).

\begin{tabular}{|c|c|c|c|c|c|c|c|c|c|}
\hline No. & Loc. & Sample level & Lab. No. & $\begin{array}{c}\mathrm{T} \\
{ }^{14} \mathrm{C} \mathrm{BP}\end{array}$ & $\begin{array}{c}\text { Calibrated age BP } \\
\text { Range } 68.2 \%\end{array}$ & $\begin{array}{c}\text { Calibrated age BP } \\
\text { Range } 95.4 \%\end{array}$ & $\begin{array}{l}\text { Cal BP } \\
\text { Mean }\end{array}$ & $\begin{array}{l}\text { Cal BP } \\
\text { Median }\end{array}$ & Chronozone \\
\hline $\mathrm{R} 1$ & 1 & $0-20 \mathrm{~cm}$ & GdA-2633 (1) & $6,030 \pm 25$ & $6,420-6,311$ & $6,477-6,279$ & 6,374 & 6,373 & Atlantic \\
\hline $\mathrm{R} 2 \mathrm{a}$ & 3 & $80-105 \mathrm{~cm}$ & Poz-37566 (2) & $9,980 \pm 50$ & $10,984-10,761$ & $11,078-10,688$ & 10,878 & 10,876 & Preboreal \\
\hline $\mathrm{R} 2 \mathrm{~b}$ & 3 & $80-105 \mathrm{~cm}$ & Poz-37567 (2) & $10,010 \pm 50$ & $11,029-10,805$ & $11,105-10,718$ & 10,913 & 10,915 & Preboreal \\
\hline $\mathrm{R} 2 \mathrm{c}$ & 3 & $80-105 \mathrm{~cm}$ & Poz-37568 (2) & $10,050 \pm 50$ & $11,086-10,871$ & $11,140-10,755$ & 10,959 & 10,967 & Preboreal \\
\hline $\mathrm{R} 2 \mathrm{~d}$ & 3 & $80-105 \mathrm{~cm}$ & Poz-37569 (2) & $10,080 \pm 50$ & $11,116-10,919$ & $11,165-10,789$ & 10,993 & 11,006 & Preboreal \\
\hline $\mathrm{R} 2 \mathrm{e}$ & 3 & $80-105 \mathrm{~cm}$ & Poz-37570 (2) & $10,090 \pm 50$ & $11,126-10,934$ & $11,173-10,800$ & 11,005 & 11,018 & Preboreal \\
\hline R3 & 4 & $0-25 \mathrm{~cm}$ & GdA-2635 (1) & $6,060 \pm 25$ & $6,463-6,345$ & $6,517-6,293$ & 6,406 & 6,406 & Atlantic \\
\hline $\mathrm{R} 4$ & $5 \mathrm{SW}$ & $1350 \mathrm{~cm}$ & GdA-2636 (1) & $10,610 \pm 30$ & $11,951-11,690$ & $12,015-11,452$ & 11,779 & 11,800 & Younger Dryas \\
\hline $\mathrm{R} 5$ & $5 \mathrm{NE}$ & $860 \mathrm{~cm}$ & GdA-2637 (1) & $11,740 \pm 35$ & $13,234-13,108$ & $13,305-13,030$ & 13,167 & 13,169 & Allerød \\
\hline R6 & $5 \mathrm{SW}$ & $705 \mathrm{~cm}$ & GdA-2638 (1) & $9,770 \pm 30$ & $10,666-10,545$ & $10,741-10,482$ & 10,606 & 10,605 & Preboreal \\
\hline R7 & $5 \mathrm{SW}$ & $90 \mathrm{~cm}$ & GdA-2639 (1) & $9,640 \pm 30$ & $10,529-10,379$ & $10,574-10,277$ & 10,440 & 10,446 & Preboreal \\
\hline $\mathrm{R} 8$ & 6 & $870 \mathrm{~cm}$ & AAR-6533 (3) & $9,860 \pm 80$ & $10,837-10,581$ & $11,005-10,505$ & 10,734 & 10,721 & Preboreal \\
\hline R9 & 6 & $250 \mathrm{~cm}$ & AAR-6534 (3) & $9,750 \pm 75$ & $10,690-10,479$ & $10,821-10,327$ & 10,580 & 10,580 & Preboreal \\
\hline- & Stormo & - & $\mathrm{T}-110(4)$ & $11,500 \pm 400$ & $13,374-12,554$ & $13,849-11,908$ & 12,911 & 12,926 & Allerød \\
\hline
\end{tabular}

stratigraphically above younger shells in locality 5 . Evidence for any diagenetic mineral precipitation is absent. Also there are no barriers to vertical flow of porewater so that waters of different ages could not be kept separately. Reworking of dated shell material remains to be the simplest explanation.

Shells within the fine-grained intervals are generally better preserved than those in the coarse-grained intervals, where they are more severely deteriorated by being more fragmented and dissolved (Fig. 9). Shell disintegration into microscopic structural elements is evident in samples from these coarse-grained intervals. Lithological characteristics (Hilmo 2011) can explain the grade of shell preservation. The coarse-grained sediments allowed increased groundwater flow and, after additional glacio-isostatic uplift, meteoric water. The acidity of the meteoric pore water was probably crucial for shell dissolution.

Because the shells can have different mineralogy and microstructures, these factors are crucial for potential dissolution rate (e.g. Nielsen et al. 2004, 2008). The dissolution process may well have influenced the shell diversity and quantity so that a number of poorly preserving species is likely to be particularly underrepresented in the upper part of the succession.

\section{Life position and sedimentary burial}

Escaping capability during catastrophic burial is essential to the benthic invertebrates living in areas of variable sedimentation rates and erosion, that is, conditions typical to the deltaic fjord system. The macrofauna of this study is rich in burrowing bivalves (Tab. 1). These bivalves are characteristic of habitats with softground to looseground, preferentially of sandy mud to muddy sand. For example, Mya truncata lives in vertical burrows within the substrate, where adults live deeply buried (Petersen 1999). Once catastrophically buried, the Mya juveniles turn the anterior upwards and attempt to pull themselves out; the adult specimens loose this ability (Schäfer 1962). Shells of both juveniles and adults of $M$. truncata are generally preserved within-habitat of the bottomset deposits of this study. This indicates a low sedimentation rate, interrupted by infrequent catastrophic burial events. The absence of large shells in the foresets may be related to (1) increased mortality of pre-mature individuals, or (2) hydrodynamic sorting before final deposition.

Arctica islandica, Cerastoderma edule and Macoma calcarea are other known burrowers (e.g. Petersen 1958, Tebble 1976). They commonly tolerate habitats with moderate water currents and recurring erosion and deposition pulses. Cerastoderma edule is capable of emergence after sudden burial with sediment during storms (Richardson et al. 1993), however, a major event of sedimentation would trap them (Schäfer 1962). Macoma calcarea burrows efficiently and its extensive mantle fusion protects the species against damaging even if sediment is entering the mantle cavity (Kranz 1974). This may explain why shells of $M$. calcarea can be found sporadically in situ within the fine-grained foresets. Abra nitida is a deeply burrowing bivalve in muddy sediments and fine sand, primarily surface deposit-feeding (e.g. Wikander 1980, Grémare et al. 2004).

Arctica islandica prefers muddy and sandy substrates and is highly resilient to abrupt sediment deposition (Powilleit et al. 2009). The species is common in the muddy bottomsets (Fig. 7, Tab. 1) but uncommon in the 

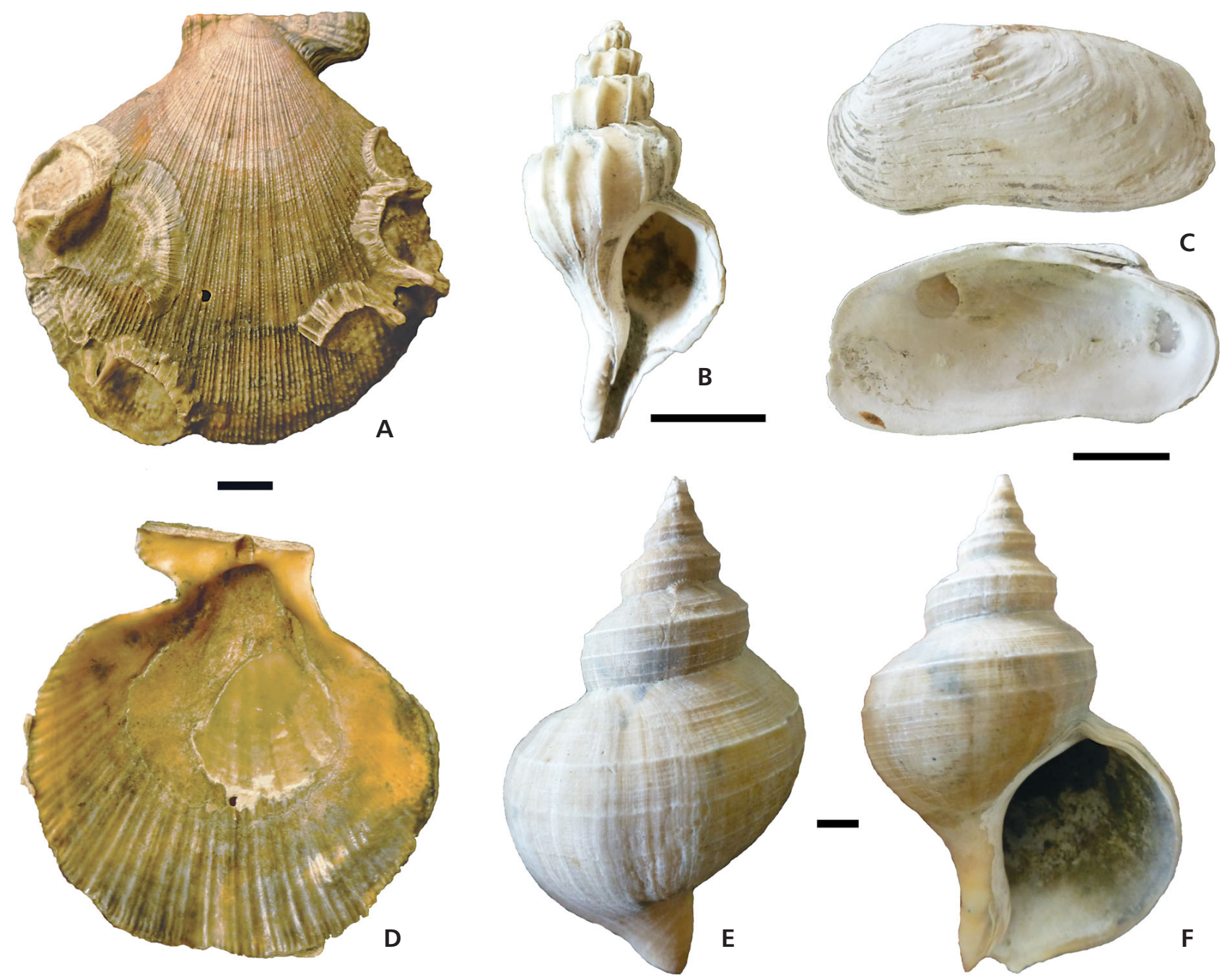

Figure 8. Common species of bivalves, barnacles and gastropods from locality 3 (sample H80-105 cm). Inner and outer shell surfaces of valves. $\bullet$ A, D - Chlamys islandica (Müller, 1776). $\bullet$ B - Boreotrophon clathratus (Linnaeus, 1767). $\bullet$ C - Hiatella arctica (Linnaeus, 1758). $\bullet$ E, F - Neptunea despecta (Linnaeus, 1758). Scale bar $10 \mathrm{~mm}$.

sandy and gravely foresets, which can be explained by sporadically high hydrodynamic levels such as storms preventing population survival and recruitment in shallow waters (Rees et al. 1977). It is characterised by low recruitment rate (e.g. Witbaard \& Bergman 2003) and adult growth (Helama et al. 2014). The life span of the species can be more than 100 years, with modal age for the Middle Atlantic Bight population at 65-105 years (Thompson et al. 1980). Arctica islandica shells of Preboreal age (mean ages 10,878-11,005 cal BP; Tab. 2) from our succession were previously found to contain between 35 and 169 annual increments, with an average lifespan of 105 years. The mean chronology of these increments (i.e. sclerochronology) was characterised by shell growth variability of 3.7- and 4.3-year periodicities (Helama et al. 2014). The demonstrated growth variations suggested that the North Atlantic Oscillation (Hurrell 1995, Hurrell \& Deser 2010) may have had a strong influence on this environmental setting during the Preboreal. This oscillation may have driven the phytoplankton production in fjords (Lindahl et al. 1998) and the supply of food to these bivalves (Helama et al. 2007), both the primary production and food supply belonging to most essential factors causing the variations in shell growth (Witbaard 1996). Also, the correlation statistics of annual increment data may be of value for interpreting the bivalve life conditions. The incremental series of our Preboreal A. islandica shells have an average correlation of 0.36 among the series (Helama et al. 2014). For modern live caught shell material, the mean correlation among the A. islandica shells from a site in northernmost Norway was seen to vary between 0.36 and 0.73 (Mette et al. 2015). The relatively low correlation found in shells from Breivikeidet muddy bottomsets likely results from growth disturbance that 


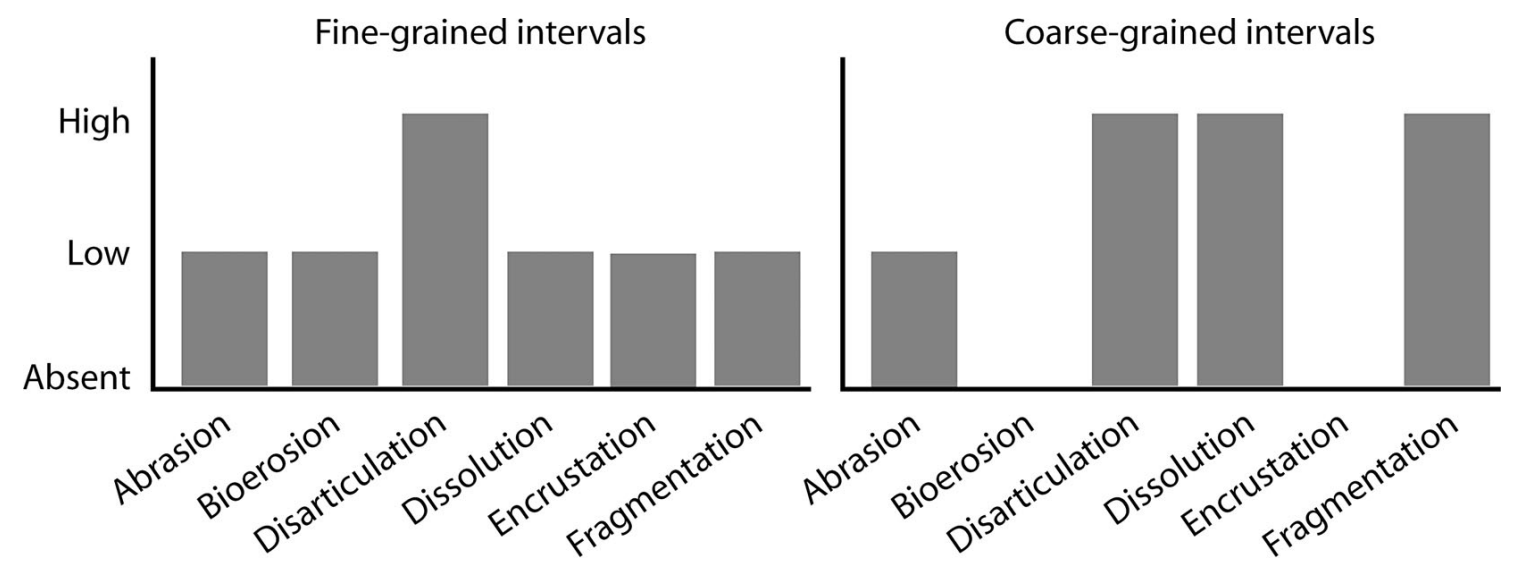

Figure 9. Overall shell preservation in the fine-grained and coarse-grained intervals of the stratigraphical succession.

Table 3. Geochemistry of sediment samples.

\begin{tabular}{|c|c|c|c|c|c|c|c|c|}
\hline \multicolumn{3}{|c|}{ Locality 3} & \multicolumn{3}{|c|}{ Locality 4} & \multicolumn{3}{|c|}{ Locality 5} \\
\hline Level $(\mathrm{cm})$ & TOC (wt $\%)$ & TS (wt $\%)$ & Level $(\mathrm{cm})$ & TOC (wt $\%)$ & TS (wt $\%)$ & Level $(\mathrm{cm})$ & TOC (wt $\%)$ & $\mathrm{TS}(\mathrm{wt} \%)$ \\
\hline 12 & 0.172 & 0.606 & 0 & 0.596 & 0.56 & 15 & 0.0912 & 0.068 \\
\hline 17 & 0.0923 & 0.0142 & 30 & 0.702 & 0.766 & 60 & 0.108 & 0.0742 \\
\hline 118 & 0.117 & 0.145 & 60 & 0.463 & 0.505 & 584 & 0.123 & 0.109 \\
\hline 137 & 0.124 & 0.0894 & 85 & 0.491 & 0.239 & 592 & 0.15 & 0.126 \\
\hline 152 & 0.117 & 0.114 & 110 & 0.258 & 0.0869 & 624 & 0.119 & 0.0979 \\
\hline 157 & 0.126 & 0.142 & 235 & 0.173 & 0.00832 & 675 & 0.0913 & 0.0705 \\
\hline 187 & 0.112 & 0.0691 & 250 & 0.222 & 0.0102 & 689 & 0.139 & 0.121 \\
\hline 217 & 0.103 & 0.25 & 470 & 0.109 & 0.0112 & 694 & 0.128 & 0.102 \\
\hline 263 & 0.116 & 0.213 & & & & 832 & 0.119 & 0.08 \\
\hline 285 & 0.105 & 0.0988 & & & & & & \\
\hline 300 & 0.101 & 0.0216 & & & & & & \\
\hline
\end{tabular}

non-catastrophically has affected the bivalve population during shell formation. Such disturbance was likely present in the fjord prodelta.

Mytilus edulis and barnacles live sessile on hard substrates such as rocks, shells and sea weed. Despite high mortality of the larval and post-settlement stages (Jørgensen 1981), specimens of M. edulis may become about twenty years old (Theisen 1973). The presence of large shells, which are preserved within-habitat in muddy bottomsets, indicates limited sedimentation over an interval of several years. Abrupt depositional event of mud may have led to final burial of the fauna, as indicated by weak parallel bedding (Fig. 3).

\section{Abiotic living conditions}

The fossil macrofauna comprises species that are still living today, and their ecology relevant for Quaternary deposits is shown in Table 4, and per sample in Table 5. Such information is used under the assumption that the fossil macrofauna (Tab. 1) is preserved within the sediment that once represented its habitat.

Most of the species are typical of shallow waters of fjords and nearshore shelf setting (e.g. Crenella decussata, Macoma balthica, Mya truncata, Mytilus edulis) (Tab. 4), which match well with the present bathymetry of Ullsfjord and the present mountain topography enclosing the Breivikeidet valley (Fig. 1). The outer Ullsfjord is open outwards and about 80-280 m depth, without any sill at the entrance (Soot-Ryen 1934, Sælen 1950). Further into the fjord there is a shallow sill $(10 \mathrm{~m})$ as access to the inner parts of the fjord system. Tidal currents intensely mix and replace water in the outer Ullsfjord as well as its inner parts (Sælen 1950). The tide is in the mesotidal range (Kartverket 2015), and we assume tide of the same magnitude to have occurred during the early Holocene even though the study area represented depositional conditions in a shallower water and were more confined topographically. Nevertheless, the waters were probably well circulated by waves, tide and particularly river outlet with water discharge to the fjord at that time. Plotting the radiocarbon 

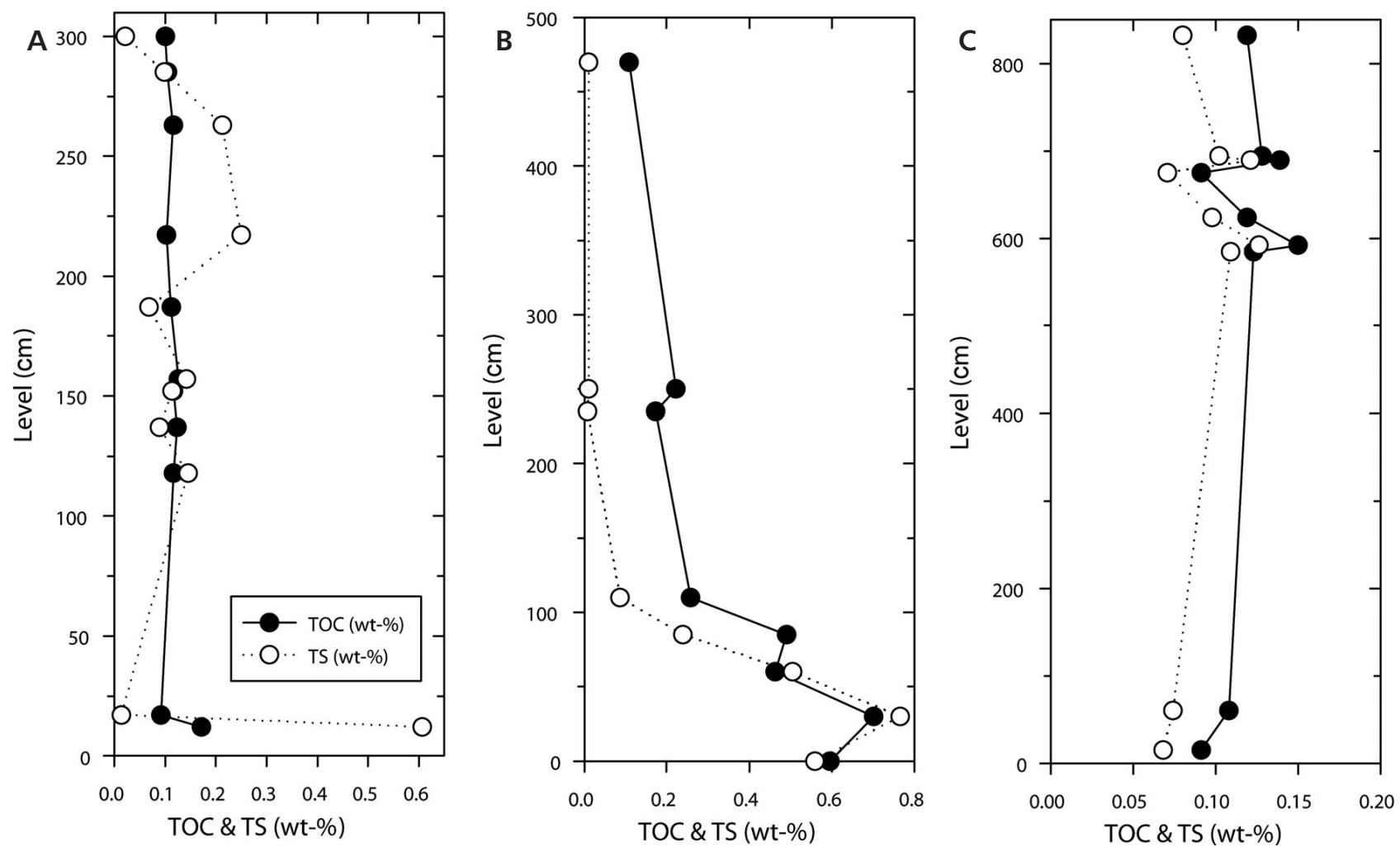

Figure 10. Total organic carbon (TOC) and total sulphur (TS) for A - locality 3, B - locality 4, and C - locality 5 .

dates from the study area with the shoreline-displacement curve from the nearby Lyngen confirm the shallowness of the area during deposition (Fig. 11). Only one species, Thyasira sarsii, is atypical of shallow waters (Tab. 4), but it is also known from $50 \mathrm{~m}$ depth on the Norwegian shelf and fjords with detritus rich sediments to allow for bacterial symbiosis (Dufour 2005, Oliver et al. 2016). Plant detritus is visually present in the sediments of this study. Temporary plumes of brackish water may have occurred locally, bringing out the detritus. Most species have broad ranges of salinity tolerance (Tab. 4) and, therefore, normal marine to somewhat brackish conditions could have existed during deposition of the bottomsets and foresets. For comparison, salinity measurements from the present outer Ullsfjord are available from a station $1\left(69^{\circ} 40.7^{\prime} \mathrm{N}, 19^{\circ} 43.3^{\prime} \mathrm{E}\right)$ off Breivikeidet (Aure et al. 1996). Averaged measurements from Nov./Dec. 1975-1994 were c. 32.5-34.2\%o in the upper $50 \mathrm{~m}$ of water, while the temperature was $c .4 .3-8.0^{\circ} \mathrm{C}$. The nearby station U4 investigated by Soot-Ryen (1934) showed July 1930 measurements at c. $6.0-10.6{ }^{\circ} \mathrm{C}$ and $30.5(?)-33.5 \%$ o. Comparing with living conditions known for the identified species (Tabs 4, 5), these ranges would have upheld the faunal populations during early Holocene.

The macrofaunal diversity of the bottomsets indicates aerobic habitat conditions during deposition. Clearly, oxygenation was not a limiting factor, which is also supported by our geochemical results (see below). At present, the outer Ullsfjord off Breivikeidet holds well oxygenated waters in the upper $50 \mathrm{~m}$ (Soot-Ryen 1934, Aure et al. 1996). During Nov./Dec. 1975-1994, the averages were $c$. 6.0-7.0 ml/1 (Aure et al. 1996). The 1930 measurements from Soot-Ryen (1934) were in the same range at the nearby station U4, that is, July 6.6-7.0 $\mathrm{ml} / 1$ and October 6.2-6.4 ml/1. Well circulated waters probably ensured that benthos continuously had aerobic conditions in our study area also during early Holocene.

\section{Geochemical evidence}

Our TOC and TS values (Tab. 3) are comparable with corresponding $\mathrm{C} / \mathrm{S}$ ratios that commonly vary between 0.5 and 5.0 under normal marine conditions. The margin values for sediments deposited in freshwater usually has a higher $\mathrm{C} / \mathrm{S}$ ratio above 10 (Berner \& Raiswell 1984). The relatively high ratio for freshwater deposits is related to a significantly lower concentration of dissolved sulphate than usually found in seawater. The $\mathrm{C} / \mathrm{S}$ ratio is below 0.5 for deposits formed under euxinic bottom-water conditions (Leventhal 1995). Because of the high concentration of hydrogen sulphide, such conditions are commonly characterised by more pyrite relative to organic matter (Raiswell $\&$ Berner 1986). Such large content of pyrite sulphur and the less good correlation between amounts of organic car- 
Table 4. Living conditions recorded for molluscs from Northeast Atlantic. Brackets indicate maximum temperature under normal marine salinity only. Abbreviations: L - intertidal, SST - sea-surface temperature. Data for molluscs mainly extracted from Peacock (1993 and references therein). Additional data stated with references. Notes: Ref. 1 = Thorson (1933); Ref. $\mathbf{2}=$ Thorson (1934); Ref. 3 = Ockelmann (1958); Ref. 4 = Oliver et al. (2016); Ref. 5 = Dufour (2005); Ref. 6 = Jensen \& Spärck (1934); Ref. 7 = Russell \& Petersen (1973); Ref. 8 = Petersen \& Russell (1973); Ref. $9=$ Wikander (1980); Ref. 10 = Wiborg (1963); Ref. 11 = Darwin (1854a); Ref. 12 = Broch (1924); Ref. 13 = Stephensen (1933); Ref. 14 = Poulsen (1935); Ref. $15=\operatorname{Kerckhof}(2002)$.

\begin{tabular}{|c|c|c|c|c|c|c|c|c|c|}
\hline \multirow[t]{2}{*}{ Species } & \multicolumn{2}{|c|}{ Temperature $\left({ }^{\circ} \mathrm{C}\right)$} & \multicolumn{2}{|c|}{ Salinity $(\% o)$} & \multicolumn{2}{|c|}{ Depth (m) } & \multicolumn{3}{|c|}{ Notes } \\
\hline & Range & $\begin{array}{c}\text { Minimum } \\
\text { summer } \\
\text { SST }\end{array}$ & $\begin{array}{l}\text { Normal } \\
\text { minimum }\end{array}$ & $\begin{array}{l}\text { Minimum } \\
\text { (Baltic } \\
\text { Sea) }\end{array}$ & $\begin{array}{l}\text { Common } \\
\text { range }\end{array}$ & $\begin{array}{l}\text { Total } \\
\text { range }\end{array}$ & Temperature $\left({ }^{\circ} \mathrm{C}\right)$ & Salinity $(\% o)$ & Depth (m) \\
\hline \multicolumn{10}{|l|}{ Gastropoda } \\
\hline $\begin{array}{l}\text { Boreotrophon } \\
\text { clathratus }\end{array}$ & $-1-8$ & 5 & $25 ?$ & - & $10-600$ & $8-1000$ & - & - & - \\
\hline Buccinum undatum & $-1-19 ?$ & - & 15 & 8 & - & $0-1200$ & - & - & - \\
\hline Lepeta caeca & - & - & 32 & 12 & - & $5-200$ & - & - & - \\
\hline Littorina littorea & $-2-20$ & $9 ?$ & 20 & 9 & $\mathrm{~L}$ & $\mathrm{~L}-60$ & - & - & - \\
\hline Neptunea despecta & $-1-16$ & - & 27 & - & - & $10-1200$ & - & - & - \\
\hline \multicolumn{10}{|l|}{ Bivalvia } \\
\hline Abra nitida & - & 10 & 20 & 11 & - & $10-300$ & - & - & $\begin{array}{l}\text { Just sublittoral to } \\
\text { 4400 Ref. } 9 .\end{array}$ \\
\hline $\begin{array}{l}\text { Acanthocardia } \\
\text { echinata }\end{array}$ & $0-12$ & 9 & 25 & 12 & $0-75$ & $0-100$ & - & - & - \\
\hline Arctica islandica & $0-20$ & 8.5 & 10 & - & - & $0-100$ & $\begin{array}{l}\text { Maximum winter } \\
\text { temperature } 10\end{array}$ & - & - \\
\hline Astarte borealis & $-2-15$ & - & 15 & 8 & - & $0-40$ & - & - & 0-463 Ref. 1, 2, 3. \\
\hline Astarte elliptica & $-1-15$ & - & 22 & 8 & - & $2-440$ & $\begin{array}{l}\text { Maximum winter } \\
\text { temperature } 7.5\end{array}$ & - & 2-442 Ref. 1, 2. \\
\hline Axinopsida orbiculata & $-2-9$ & - & - & - & $5-70$ & $5-460$ & - & Euryhaline & $\begin{array}{l}2-944 \text { Ref. 3, } 30 \\
\text { Ref. } 5 .\end{array}$ \\
\hline Cerastoderma edule & $-1-?$ & 9 & 15 & 5 & $\mathrm{~L}-2$ & $\mathrm{~L}-46$ & $\begin{array}{l}\text { 3-25 Ref. 7. Larval } \\
\text { development 15-25 }\end{array}$ & $\begin{array}{l}\text { 15-35 Ref. } 7, \mathbf{8} \text {. } \\
\text { Larval development } \\
20-40\end{array}$ & $\begin{array}{l}\text { Prefer tidal habitat, } \\
\text { amplitude } 0.2-10 \\
\text { Ref. 7, 8. Common } \\
\text { range 0-10 Ref. } 8 \text {. }\end{array}$ \\
\hline Chlamys islandica & $-2-14(6)$ & - & - & - & - & $7-80$ & $\begin{array}{l}\text { Bottom temperature } \\
1-9.5 \text { in fjords with } \\
\text { sill at entrance in } \\
\text { North Norway Ref. } \\
\text { 10. Minimum for } \\
\text { larvae } 8 \text {; minimum } \\
\text { for spawning } 5\end{array}$ & Euryhaline & $\begin{array}{l}\text { 2-356 Ref. } 2, \mathbf{3} \text {. } \\
\text { 4-250 or even more, } \\
\text { greatest } \\
\text { concentrations most } \\
\text { often at } 10-60 \text { in } \\
\text { fjords with sill at } \\
\text { entrance in North } \\
\text { Norway Ref. 10. }\end{array}$ \\
\hline Crenella decussata & $-2-15$ & 4 & 23 & 12 & $15-30$ & $4-70$ & - & - & $\begin{array}{l}\text { Typically 4-70, } \\
\text { 2-1100 Ref. } 3 \text {. }\end{array}$ \\
\hline Hiatella arctica & - & - & 20 & 11 & $\mathrm{~L}-75$ & $\mathrm{~L}-120$ & - & - & 0-2190? Ref. 3. \\
\hline Macoma balthica & $-2-22$ & 7 & 2 & & $0-25$ & $\mathrm{~L}-45$ & - & - & $\begin{array}{l}\text { Commonly as low as } \\
2-3 \text { in relative calm } \\
\text { waters. }>50 \text { in } \\
\text { Baltic Sea Ref. } 6 .\end{array}$ \\
\hline
\end{tabular}

bon and pyrite sulphur typically indicative of euxinic conditions (Raiswell \& Berner 1986), however, have not been observed for the studied localities.

The TOC/TS ratio varies through the fine-grained terrigenous sediments in the locality 3. Overall the TOC/TS ratios in Fig. 3 indicate deposition under marine conditions that are confirmed by high content of shell material of marine origin. The amounts of organic matter and pyrite sulphur follow each other to a lesser degree than observed at the localities 4 and 5 (Fig. 10A, Tab. 3). Somewhat larger TS values are recorded at the base of locality 3 . The geochemical plot for the locality 4 indicates that the depositional conditions changed during the lower $5 \mathrm{~m}$ of the succession (Fig. 4). The TOC/TS ratio changes from normal marine conditions in the lowest part of the succession to freshwater for the upper three samples. Both the TOC and 
Table 4. continued.

\begin{tabular}{|c|c|c|c|c|c|c|c|c|c|}
\hline \multirow[t]{2}{*}{ Species } & \multicolumn{2}{|c|}{ Temperature $\left({ }^{\circ} \mathrm{C}\right)$} & \multicolumn{2}{|c|}{ Salinity $(\% o)$} & \multicolumn{2}{|c|}{ Depth (m) } & \multicolumn{3}{|c|}{ Notes } \\
\hline & Range & $\begin{array}{c}\text { Minimum } \\
\text { summer } \\
\text { SST }\end{array}$ & $\begin{array}{l}\text { Normal } \\
\text { minimum }\end{array}$ & $\begin{array}{l}\text { Minimum } \\
\text { (Baltic } \\
\text { Sea) } \\
\end{array}$ & $\begin{array}{c}\text { Common } \\
\text { range }\end{array}$ & $\begin{array}{l}\text { Total } \\
\text { range }\end{array}$ & Temperature $\left({ }^{\circ} \mathrm{C}\right)$ & Salinity $(\% \circ)$ & Depth (m) \\
\hline Macoma calcarea & $\begin{array}{c}-2-16 \\
(11)\end{array}$ & 5 & 13 & 8 & - & $0-80$ & $\begin{array}{l}\text { Larval development } \\
5-6 \text { at } N \text { and } S \text { limits }\end{array}$ & - & 0-677 Ref. 3. \\
\hline $\begin{array}{l}\text { Mya truncata sensu } \\
\text { lato }\end{array}$ & $-2-17$ & 4.5 & 17 & 8 & $\mathrm{~L}-50$ & $\mathrm{~L}-70$ & $\begin{array}{l}\text { Maximum winter } \\
\text { temperature } 8\end{array}$ & - & 0-625 Ref. 3. \\
\hline Mytilus edulis & $-10-30$ & 4 & 7 & - & $\mathrm{L}-10$ & $\mathrm{~L}-25$ & - & Normally $15-40$ & $\begin{array}{l}\text { L-180, uncommon } \\
\text { below } 50 \text { Ref. } 3 \text {. } \\
\text { Mainly littoral }\end{array}$ \\
\hline Nuculana pernula & $-2-14(8)$ & - & 25 & 12 & - & $5-1275$ & $\begin{array}{l}\text { Maximum winter } \\
\text { temperature } 6\end{array}$ & - & 3-1275 Ref. 2, 3. \\
\hline Panomya norvegica & - & - & - & - & - & - & - & - & 4-500 Ref. 6. \\
\hline $\begin{array}{l}\text { Parvicardium } \\
\text { exiguum }\end{array}$ & - & 10.5 & 10 & - & $0-20$ & $0-55$ & $\begin{array}{l}3-25 \\
\text { Ref. } 7\end{array}$ & $\begin{array}{l}\text { Brackish to normal } \\
\text { marine Ref. } \mathbf{6} \text {. } \\
\text { 25-35 Ref. } \mathbf{7}, \mathbf{8} \text {. } \\
\text { Minimum for larvae } \\
20\end{array}$ & $\begin{array}{l}\text { Shallow waters Ref. } \\
\text { 6. Tidal amplitude } \\
\text { 0-10 Ref. } 7 \text {. Prefer } \\
\text { tidal and lagoon, } \\
\text { 0-55 Ref. 8. }\end{array}$ \\
\hline $\begin{array}{l}\text { Parvicardium } \\
\text { minimum }\end{array}$ & $4.5-?$ & 8.5 & 25 & 12 & $100-150$ & $9-400$ & - & - & 30-2000 Ref. 6. \\
\hline Phaxas pellucidus & - & 12 & 20 & 9 & $4-40$ & $4-150$ & - & - & - \\
\hline $\begin{array}{l}\text { Similipecten } \\
\text { greenlandicus }\end{array}$ & $-2-9$ & - & 33 & - & - & $60-?$ & - & - & 4-2000 Ref. 1, 3. \\
\hline Thyasira sarsii & - & - & 33.5 & 23 & - & $100-600$ & - & - & $\begin{array}{l}\text { 80-220, fjords Ref. } \\
\text { 4. } 50-340 \text { Ref. } 5 \text {. }\end{array}$ \\
\hline Yoldiella lenticula & $-1-8.5$ & - & 33 & - & - & $10-300$ & $\begin{array}{l}\text { Maximum winter } \\
\text { temperature } 4.5\end{array}$ & - & 0-1400 Ref. 2, 3. \\
\hline \multicolumn{10}{|l|}{ Cirripedia } \\
\hline Balanus balanus & - & - & - & $\begin{array}{c}14 \\
\text { Ref. } 14\end{array}$ & - & $\begin{array}{c}0-300 \\
\text { Ref. } 12\end{array}$ & - & - & $\begin{array}{l}\text { 5-50 fathoms Ref. } \\
\text { 11. Few metres (in } \\
\text { north)-300 Ref. } 13 . \\
\text { 5-130 in Danish } \\
\text { waters Ref. } \mathbf{1 4 .}\end{array}$ \\
\hline Balanus crenatus & - & - & - & $\begin{array}{c}9 \\
\text { Ref. } 14\end{array}$ & - & $\begin{array}{c}0-320 \\
\text { Ref. } 12\end{array}$ & - & $\begin{array}{l}\text { Prefers normal } \\
\text { marine conditions } \\
\text { Ref. } 15\end{array}$ & $\begin{array}{l}\text { Down to } 50 \text { fathoms } \\
\text { Ref. 11. } 0-100 \text { or } \\
\text { more Ref. 13. 0-60 } \\
\text { in Danish waters } \\
\text { Ref. 14. }\end{array}$ \\
\hline Verruca stroemia & - & - & $\begin{array}{c}20 \\
\text { Ref. } 14\end{array}$ & - & $\begin{array}{l}5-200 \\
\text { Ref. } 14\end{array}$ & $\begin{array}{c}0-548 \\
\text { Ref. } 12\end{array}$ & - & - & $\begin{array}{l}\text { Tidal-50-90? } \\
\text { fathoms Ref. } 11 . \\
\text { 0-200 Ref. } 13 .\end{array}$ \\
\hline
\end{tabular}

TS values gradually change; however, the TS values decrease faster than those of TOC (Fig. 10B). This indicates a limitation in sulphur availability, causing higher TOC/TS values towards the top of the succession. All the TOC/TS ratios for the locality 5 are within the range for normal marine conditions (Fig. 5), where the amounts of carbon and sulphur vary only slightly throughout the section (Fig. 10C).

\section{Benthic faunal communities}

Taxa from our localities (Tab. 1) can be related to modern benthic communities in shallow-marine waters, defined in the classical investigations by Petersen $(1913,1914,1918$, 1924). The communities were classified after recurring associations of certain animals and named after the most conspicuous species. The Macoma calcarea community comprises the characterising animals Macoma calcarea, Mya truncata, Cardium ciliatum, Serripes groenlandicus, Ophiocten scriceum, Pectinaria granulata, Astarte borealis, A. elliptica, and A. montagui (Thorson 1933, 1934, 1957). Some of these may be absent. The community is circumpolar on mixed bottoms from 4 to 50-60 m depth, even down to $100-130 \mathrm{~m}$ in the Barents Sea and at Spitsbergen (Thorson 1957). Many of the taxa (Tab. 1) are known from the Macoma calcarea community, which matches well with 
Table 5. Minimum summer sea-surface temperature and normal minimum salinity (Tab. 4) and zoogeographical provinces (Tab. 6) compiled per sample, with the doubtful assumption that the shell material in every sample was preserved within habitat. Data from the Baltic Sea are excluded as they originate from a different oceanographic setting. Abbreviations: SST - sea-surface temperature; B - boreal; MB - mid boreal; HB - high boreal; LA - low arctic.

\begin{tabular}{|c|c|c|c|c|}
\hline \multirow[t]{2}{*}{ Locality } & \multirow[t]{2}{*}{ Level $(\mathrm{cm})$} & \multirow{2}{*}{$\begin{array}{c}\text { Temperature }\left({ }^{\circ} \mathrm{C}\right) \\
\text { Minimum summer } \\
\text { SST }\end{array}$} & \multirow{2}{*}{$\begin{array}{c}\text { Salinity }(\% o) \\
\begin{array}{c}\text { Normal } \\
\text { minimum }\end{array}\end{array}$} & \multirow[t]{2}{*}{ Zoogeography } \\
\hline & & & & \\
\hline 1 & $0-20$ & 8.5 & 23 & HB \\
\hline 3 & $50-70$ & 5 & 33 & $\mathrm{MB}, \mathrm{HB}$ \\
\hline 3 & $80-105$ & 10 & 12 & $\mathrm{HB}$ \\
\hline 3 & H80-105 & 10 & 27 & $\mathrm{MB}, \mathrm{HB}$ \\
\hline 3 & $205-225$ & 10 & 23 & $\mathrm{HB}$ \\
\hline 3 & $305-325$ & 10 & 23 & $\mathrm{MB}, \mathrm{HB}$ \\
\hline 4 & $0-25$ & 8.5 (9?) & 33.5 & HB \\
\hline 6 & $220-240$ & 10 & 33 & $\mathrm{HB}$ \\
\hline 6 & $240-260$ & 10.5 & 25 & B \\
\hline 6 & $285-305$ & 10 & 33 & $\mathrm{HB}$ \\
\hline 6 & $425-435$ & 10 & 33 & $\mathrm{HB}$ \\
\hline 6 & $450-470$ & 12 & 25 & B \\
\hline 6 & $495-515$ & 5 & 17 & B \\
\hline 6 & $545-555$ & 9 & 17 & B \\
\hline 6 & $650-670$ & $5(9 ?)$ & 20 & $\mathrm{~B}, \mathrm{LA}$ \\
\hline 6 & $805-825$ & $5(9 ?)$ & 20 & B \\
\hline 6 & $860-870$ & 9 & 27 & B \\
\hline 6 & $870-880$ & 9 & 17 & B \\
\hline 6 & $1000-1015$ & Indet. & Indet. & Indet. \\
\hline
\end{tabular}

the grain size and sorting of the associated sediments. For example, Macoma calcarea lives in clayey or muddy bottoms that may be mixed with sand, gravel and stones on shallow depth in the inner Kejser Franz Joseph Fjord, East Greenland (Ockelmann 1958). In the Ramfjord of Troms County, the Macoma calcarea community occurs especially at 2-15 $\mathrm{m}$ water depth in the inner parts of the fjord (Soot-Ryen 1924, 1932). The inner basin of the fjord showed yearly temperature range of about $0-10{ }^{\circ} \mathrm{C}$ and salinity at 27.7-33.4\%o, measured at 2-20 m water depth (Soot-Ryen 1932).

The common occurrence of Abra nitida may be due to ecological as well as preservational favouring. Its ability to both surface deposit-feeding and suspension-feeding indicates that the species is somewhat adapted to rely on an abundant food source available for short periods (Grémare et al. 2004). This would be an advantage for the variable habitat conditions and food availability in a fjord delta. Abra nitida is one of the characterising species in the Amphiura filiformis-A. chiajei community present on clayey to silty soft bottoms at about $15-100 \mathrm{~m}$ depth (Thorson 1957). It is also known from the circumpolar
Maldane sarsi-Ophiura sarsi community in fine mud bottoms of shallow estuaries and at 100-300 $\mathrm{m}$ in the open sea (Thorson 1957; see Petersen 1918).

Similar feeding modes are known for Macoma balthica. Surface suspension feeding predominates in exposed sandy sites, and deposit feeding in sheltered muddy sand (Ólafsson 1986), dependent upon food availability in the water column (Hummel 1985). Macoma balthica, Mya arenaria and Cerastoderma edule are characterising bivalves of the boreal Macoma balthica community, particularly present in estuarine conditions from the tidal zone to depths of 8-10 m (Thorson 1957; see Petersen 1913, 1918). The rareness of Macoma balthica in the fjord deltaic foresets suggests that the community was scarcely developed or of low preservation potential (Tab. 1). More sandy bottoms may hold a larger quantity of $C$. edule (Thorson 1957), explaining its presence in the foresets (Tab. 1).

Nuculana pernula lives in similar sediments and has greatest abundance in the Macoma calcarea community (Thorson 1934, Ockelmann 1958). Astarte borealis may occur in clay, sand, gravel and mixed bottom, abundant in the Gomphina fluctuosa and Macoma calcarea communities (Thorson 1933, 1934; Madsen 1949; Ockelmann 1958). Astarte elliptica can be abundant in the Macoma calcarea community, where the substrate mainly is clay, mud, sand and mixed bottom (Thorson 1933, Ockelmann 1958). Axinopsida orbiculata occurs preferentially in silt of the Macoma calcarea, Gomphina fluctuosa and Yoldia hyperborea communities (Ockelmann 1958). Yoldiella lenticula lives in mud and clay, which may contain sand and gravel, with greatest abundance in the Astarte crenata community (Thorson 1934, Ockelmann 1958). Panomya norvegica occurs deeply buried in mud, muddy and sandy gravel bottoms (Tebble 1976). Mya truncata lives in various substrates of clay, mud, sand, gravel and stones. Juveniles commonly attach to algae in large numbers, whereas adults are endobenthos in the Macoma calcarea community (Ockelmann 1958). Juveniles of Hiatella arctica also belong to the epifauna, commonly on algae in shallow waters. The adults are mainly byssally attached to stones and other hard substrates, in irregularities of the sea bottom, or numerously lumped to each other (Ockelmann 1958). Larvae are able to settle and bore into solid but soft substrates (Hunter 1949); however, no such borings were found in the study area.

Mytilus edulis belongs to the algal epifauna and hard substrates, as byssate suspension feeder on rocks, stones and seaweed preferably where currents are strong (Ockelmann 1958). It is mainly found in the tidal zone and a few metres down (e.g. Sars 1878, Ockelmann 1958). Another mytilid, Crenella decussata, is known from both sandy and muddy bottom, mixed with sand or gravel, in mainly shallow waters (Ockelmann 1958). It is very common in shallow waters at Finnmark (Sars 1878). 
Figure 11. Radiocarbon dates from this study shown in comparison with the Lyngen dates and shoreline-displacement curve by Corner \& Haugane (1993), who emphasized that the curve represents hightide level (threshold isolation level of lake).

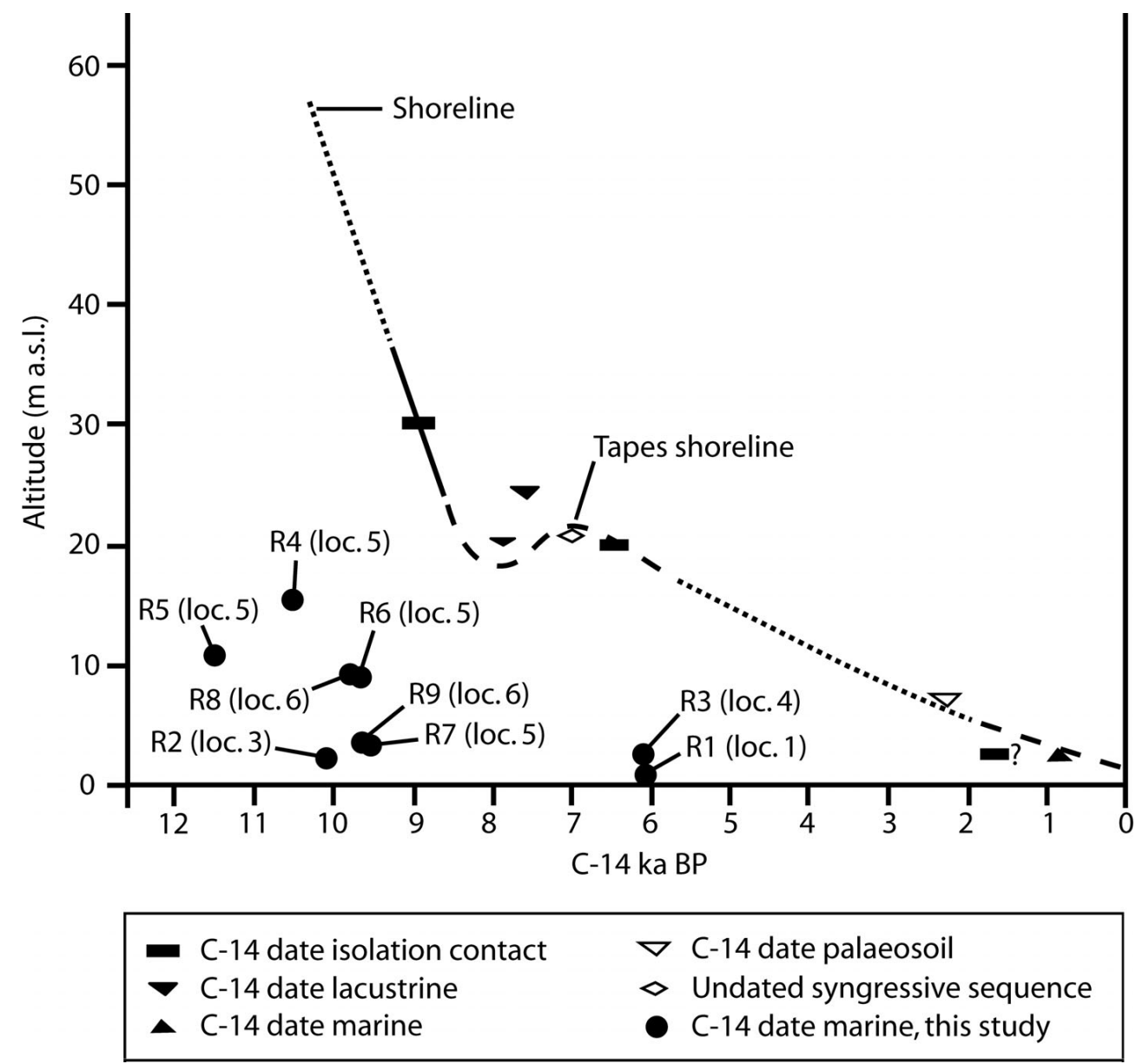

Chlamys islandica is associated with the algal epifauna; juveniles mostly live with Fucus in shallow water. Chlamys islandica can swim or lives attached by byssus to substrate or to each other (Wiborg 1962, 1963). Adults migrate to greater depths to the zone with red algae (Thorson 1934, Ockelmann 1958); the migration appears to be seasonal, into deeper water during summer and back to shallow waters during winter (Soot-Ryen 1924). This may well explain why only large shells of $C$. islandica are in the interval $80-105 \mathrm{~cm}$ of locality 3 (Fig. 3). Chlamys islandica usually lives in the North Norwegian fjords at 10-60 m where the shells typically are heavily encrusted by other organisms (Wiborg 1962, 1963). The preferred bottom is sand, gravel, shells, stones and sometimes clay, in fjords with shallow sill of 10-15 m depth or less at the entrance (Wiborg 1962, 1963). Chlamys islandica thrives in waters characterised by strong currents (Wiborg 1963). Its presence is in good agreement with the overall deltaic fjord setting during early Holocene.

Similipecten greenlandicum prefers a bottom of clay with gravel, stones and shells; it is especially abundant in lower Ophiocten zone of the Macoma calcarea community (Thorson 1933, Ockelmann 1958).
The barnacles belong to the algal epifauna and those preferring hard substrates. They live sessile with basis cemented on hard substrates, and cannot live on sand, mud or moving shingle (Darwin 1854a). Balanus balanus, B. crenatus and Verruca stroemia are usually found on molluscan shells (e.g. large pectinids, gastropods), crustaceans and rocks (Darwin 1854a, Stephensen 1933, Poulsen 1935, Kerckhof 2002). Balanus balanus prefers habitats with comparatively strong current (Rasmussen 1973). Balanus balanus, which also can be on the holdfasts of larger sea-weeds and imbedded in sponges, is commonly associated with $B$. crenatus and sometimes with $B$. hammeri and V. stroemia (Darwin 1854a). Balanus crenatus and $V$. stroemia also attaches themselves to pebbles and floating wood (Darwin 1854a). Balanus balanus, $B$. crenatus and $V$. stroemia are more or less euryhaline species (Poulsen 1935; Tab. 4).

Preservation bias probably favoured certain species and modified the community structure (e.g. Kidwell \& Bosence 1991). Still, the investigated samples primarily point towards the Macoma calcarea community. Many of the species are well known from this soft bottom community. There is also an indication of transition with other 
Table 6. Zoogeographical provinces for modern specimens of the species in the investigated fossil macrofauna. The provinces where the species are commonly living are shaded in grey. Province data compiled from biogeographical information by Darwin (1854a), Sars (1878), Stephensen (1933), Jensen \& Spärck (1934), Grønlie (1945), Feyling-Hanssen (1955), Ockelmann (1958), Wiborg (1962), Petersen \& Russell (1973), Tebble (1976), Petersen $(1977,1999)$ and GBIF $(2014 a, b, c)$. Sectoral distribution along the northern Norway extracted from Høisæter et al. (2001a, b) and Sneli \& Brattegard (2001). Abbreviations: $*=$ Zoogeographical division after Feyling-Hanssen (1955); ** = Sectoral distribution in northern Norway: 13 = Trondheimsfjorden; 14 = northwestern Sør Trøndelag; 15 = Nord Trøndelag; 16 = southern Nordland; $17=$ mid Nordland; $18=$ northern Nordland (Lofoten); 19 = southern Troms; 20 = mid Troms; 21 = northern Troms; $22=$ western Finnmark (northeast to Tarhalsen); $23=$ northwestern Finnmark (northeast to North Cape); 24 = northern Finnmark (Porsangerfjorden - Nordkinnhalvøya); 25 = northeastern Finnmark (Slettnes light - Harbaken); 26 = eastern Finnmark (Harbaken - border to Russia); N = northern species; $\mathrm{S}=$ southern species; $\mathrm{X}=$ pan-sectoral distribution (known south and north of Norway).

\begin{tabular}{|c|c|c|c|c|c|c|c|c|c|c|c|c|c|c|c|c|c|c|c|c|c|}
\hline \multirow{3}{*}{ Species } & \multicolumn{7}{|c|}{ Zoogeographical provinces $*$} & \multicolumn{14}{|c|}{ Sectoral distribution in northern Norway $* *$} \\
\hline & \multirow{2}{*}{ Lusitanian } & \multicolumn{3}{|c|}{ Boreal } & \multicolumn{3}{|c|}{ Arctic } & \multirow[b]{2}{*}{13} & \multirow[b]{2}{*}{14} & \multirow[b]{2}{*}{15} & \multirow[b]{2}{*}{16} & \multirow[b]{2}{*}{17} & \multirow[b]{2}{*}{18} & \multirow[b]{2}{*}{19} & \multirow[b]{2}{*}{20} & \multirow[b]{2}{*}{21} & \multirow[b]{2}{*}{22} & \multirow[b]{2}{*}{23} & \multirow[b]{2}{*}{24} & \multirow[b]{2}{*}{25} & \multirow[b]{2}{*}{26} \\
\hline & & Low & Mid & High & Low & Mid & High & & & & & & & & & & & & & & \\
\hline GASTROPODA & & & & & & & & & & & & & & & & & & & & & \\
\hline Littorina littorea & + & + & + & + & + & & & $\mathrm{X}$ & $\mathrm{X}$ & $\mathrm{X}$ & $\mathrm{X}$ & $\mathrm{X}$ & $\mathrm{X}$ & $\mathrm{X}$ & $\mathrm{X}$ & $\mathrm{X}$ & $\mathrm{X}$ & $\mathrm{X}$ & $\mathrm{X}$ & $\mathrm{X}$ & $\mathrm{X}$ \\
\hline Buccinum undatum & + & + & + & + & + & + & & $\mathrm{X}$ & $\mathrm{X}$ & $\mathrm{X}$ & $\mathrm{X}$ & $\mathrm{X}$ & $\mathrm{X}$ & $\mathrm{X}$ & $\mathrm{X}$ & $\mathrm{X}$ & $\mathrm{X}$ & $\mathrm{X}$ & $\mathrm{X}$ & $\mathrm{X}$ & $\mathrm{X}$ \\
\hline Boreotrophon clathratus & & + & + & + & + & + & + & $\mathrm{X}$ & $\mathrm{X}$ & $\mathrm{X}$ & $\mathrm{X}$ & $\mathrm{X}$ & $\mathrm{X}$ & $\mathrm{X}$ & $\mathrm{X}$ & $\mathrm{X}$ & $\mathrm{X}$ & $\mathrm{X}$ & $\mathrm{X}$ & $\mathrm{X}$ & $\mathrm{X}$ \\
\hline Lepeta caeca & & + & + & + & + & + & + & $\mathrm{X}$ & $\mathrm{X}$ & $\mathrm{X}$ & $\mathrm{X}$ & $\mathrm{X}$ & $\mathrm{X}$ & $\mathrm{X}$ & $\mathrm{X}$ & $\mathrm{X}$ & $\mathrm{X}$ & $\mathrm{X}$ & $\mathrm{X}$ & $\mathrm{X}$ & $\mathrm{X}$ \\
\hline Neptunea despecta & & + & + & + & + & + & + & $\mathrm{N}$ & $\mathrm{N}$ & $\mathrm{N}$ & $\mathrm{N}$ & $\mathrm{N}$ & $\mathrm{N}$ & $\mathrm{N}$ & $\mathrm{N}$ & $\mathrm{N}$ & $\mathrm{N}$ & $\mathrm{N}$ & $\mathrm{N}$ & $\mathrm{N}$ & $\mathrm{N}$ \\
\hline BIVALVIA & & & & & & & & & & & & & & & & & & & & & \\
\hline Abra nitida & + & + & + & + & & & & $\mathrm{S}$ & $\mathrm{S}$ & $\mathrm{S}$ & $\mathrm{S}$ & $\mathrm{S}$ & $\mathrm{S}$ & $\mathrm{S}$ & $\mathrm{S}$ & $\mathrm{S}$ & $\mathrm{S}$ & & & & \\
\hline Acanthocardia echinata & + & + & + & + & & & & $\mathrm{S}$ & $\mathrm{S}$ & $\mathrm{S}$ & $\mathrm{S}$ & $\mathrm{S}$ & $\mathrm{S}$ & $\mathrm{S}$ & $\mathrm{S}$ & $\mathrm{S}$ & $\mathrm{S}$ & $\mathrm{S}$ & S & & \\
\hline Cerastoderma edule & + & + & + & + & & & & $\mathrm{S}$ & $\mathrm{S}$ & $\mathrm{S}$ & $\mathrm{S}$ & $\mathrm{S}$ & $\mathrm{S}$ & $\mathrm{S}$ & $\mathrm{S}$ & $\mathrm{S}$ & $\mathrm{S}$ & $\mathrm{S}$ & $\mathrm{S}$ & $\mathrm{S}$ & \\
\hline Parvicardium exiguum & + & + & + & + & & & & $\mathrm{S}$ & $\mathrm{S}$ & $\mathrm{S}$ & $\mathrm{S}$ & $\mathrm{S}$ & $\mathrm{S}$ & $\mathrm{S}$ & $\mathrm{S}$ & $\mathrm{S}$ & & & & & \\
\hline Phaxas pellucidus & + & + & + & + & & & & $\mathrm{S}$ & $\mathrm{S}$ & $\mathrm{S}$ & $\mathrm{S}$ & $\mathrm{S}$ & $\mathrm{S}$ & $\mathrm{S}$ & $\mathrm{S}$ & $\mathrm{S}$ & $\mathrm{S}$ & & & & \\
\hline Panomya norvegica & + & + & + & + & & & & $\mathrm{N}$ & $\mathrm{N}$ & $\mathrm{N}$ & $\mathrm{N}$ & $\mathrm{N}$ & $\mathrm{N}$ & $\mathrm{N}$ & $\mathrm{N}$ & $\mathrm{N}$ & $\mathrm{N}$ & $\mathrm{N}$ & $\mathrm{N}$ & $\mathrm{N}$ & $\mathrm{N}$ \\
\hline Parvicardium minimum & + & + & + & + & & & & $\mathrm{S}$ & $\mathrm{S}$ & $\mathrm{S}$ & $\mathrm{S}$ & $\mathrm{S}$ & $\mathrm{S}$ & $\mathrm{S}$ & $\mathrm{S}$ & $\mathrm{S}$ & $\mathrm{S}$ & S & $\mathrm{S}$ & $\mathrm{S}$ & \\
\hline Arctica islandica & + & + & + & + & + & & & $\mathrm{X}$ & $\mathrm{X}$ & $\mathrm{X}$ & $\mathrm{X}$ & $\mathrm{X}$ & $\mathrm{X}$ & $\mathrm{X}$ & $\mathrm{X}$ & $\mathrm{X}$ & $\mathrm{X}$ & $\mathrm{X}$ & $\mathrm{X}$ & $\mathrm{X}$ & $\mathrm{X}$ \\
\hline Macoma balthica & + & + & + & + & + & & & $\mathrm{X}$ & $\mathrm{X}$ & $\mathrm{X}$ & $\mathrm{X}$ & $\mathrm{X}$ & $\mathrm{X}$ & $\mathrm{X}$ & $\mathrm{X}$ & $\mathrm{X}$ & $\mathrm{X}$ & $\mathrm{X}$ & $\mathrm{X}$ & $\mathrm{X}$ & $\mathrm{X}$ \\
\hline Mytilus edulis & + & + & + & + & + & + & & $\mathrm{X}$ & $\mathrm{X}$ & $\mathrm{X}$ & $\mathrm{X}$ & $\mathrm{X}$ & $\mathrm{X}$ & $\mathrm{X}$ & $\mathrm{X}$ & $\mathrm{X}$ & $\mathrm{X}$ & $\mathrm{X}$ & $\mathrm{X}$ & $\mathrm{X}$ & $\mathrm{X}$ \\
\hline Hiatella arctica & + & + & + & + & + & + & + & $\mathrm{X}$ & $\mathrm{X}$ & $\mathrm{X}$ & $\mathrm{X}$ & $\mathrm{X}$ & $\mathrm{X}$ & $\mathrm{X}$ & $\mathrm{X}$ & $\mathrm{X}$ & $\mathrm{X}$ & $\mathrm{X}$ & $\mathrm{X}$ & $\mathrm{X}$ & $\mathrm{X}$ \\
\hline Crenella decussata & + & + & + & + & + & + & + & $\mathrm{X}$ & $\mathrm{X}$ & $\mathrm{X}$ & $\mathrm{X}$ & $\mathrm{X}$ & $\mathrm{X}$ & $\mathrm{X}$ & $\mathrm{X}$ & $\mathrm{X}$ & $\mathrm{X}$ & $\mathrm{X}$ & $\mathrm{X}$ & $\mathrm{X}$ & $\mathrm{X}$ \\
\hline Mya truncata & & + & + & + & & & & $\mathrm{X}$ & $\mathrm{X}$ & $\mathrm{X}$ & $\mathrm{X}$ & $\mathrm{X}$ & $\mathrm{X}$ & $\mathrm{X}$ & $\mathrm{X}$ & $\mathrm{X}$ & $\mathrm{X}$ & $\mathrm{X}$ & $\mathrm{X}$ & $\mathrm{X}$ & $\mathrm{X}$ \\
\hline Astarte elliptica & & + & + & + & + & + & + & $\mathrm{X}$ & $\mathrm{X}$ & $\mathrm{X}$ & $\mathrm{X}$ & $\mathrm{X}$ & $\mathrm{X}$ & $\mathrm{X}$ & $\mathrm{X}$ & $\mathrm{X}$ & $\mathrm{X}$ & $\mathrm{X}$ & $\mathrm{X}$ & $\mathrm{X}$ & $\mathrm{X}$ \\
\hline Nuculana pernula & & + & + & + & + & + & + & $\mathrm{X}$ & $\mathrm{X}$ & $\mathrm{X}$ & $\mathrm{X}$ & $\mathrm{X}$ & $\mathrm{X}$ & $\mathrm{X}$ & $\mathrm{X}$ & $\mathrm{X}$ & $\mathrm{X}$ & $\mathrm{X}$ & $\mathrm{X}$ & $\mathrm{X}$ & $\mathrm{X}$ \\
\hline Thyasira sarsii & & + & + & + & + & + & & $\mathrm{X}$ & $\mathrm{X}$ & $\mathrm{X}$ & $\mathrm{X}$ & $\mathrm{X}$ & $\mathrm{X}$ & $\mathrm{X}$ & $\mathrm{X}$ & $\mathrm{X}$ & $\mathrm{X}$ & $\mathrm{X}$ & $\mathrm{X}$ & $\mathrm{X}$ & $\mathrm{X}$ \\
\hline Macoma calcarea & & + & + & + & + & + & + & $\mathrm{X}$ & $\mathrm{X}$ & $\mathrm{X}$ & $\mathrm{X}$ & $\mathrm{X}$ & $\mathrm{X}$ & $\mathrm{X}$ & $\mathrm{X}$ & $\mathrm{X}$ & $\mathrm{X}$ & $\mathrm{X}$ & $\mathrm{X}$ & $\mathrm{X}$ & $\mathrm{X}$ \\
\hline Astarte borealis & & & + & + & + & + & + & $\mathrm{N}$ & $\mathrm{N}$ & $\mathrm{N}$ & $\mathrm{N}$ & $\mathrm{N}$ & $\mathrm{N}$ & $\mathrm{N}$ & $\mathrm{N}$ & $\mathrm{N}$ & $\mathrm{N}$ & $\mathrm{N}$ & $\mathrm{N}$ & $\mathrm{N}$ & $\mathrm{N}$ \\
\hline Chlamys islandica & & & + & + & + & + & + & $\mathrm{N}$ & $\mathrm{N}$ & $\mathrm{N}$ & $\mathrm{N}$ & $\mathrm{N}$ & $\mathrm{N}$ & $\mathrm{N}$ & $\mathrm{N}$ & $\mathrm{N}$ & $\mathrm{N}$ & $\mathrm{N}$ & $\mathrm{N}$ & $\mathrm{N}$ & $\mathrm{N}$ \\
\hline Yoldiella lenticula & & & + & + & + & + & + & & $\mathrm{N}$ & $\mathrm{N}$ & $\mathrm{N}$ & $\mathrm{N}$ & $\mathrm{N}$ & $\mathrm{N}$ & $\mathrm{N}$ & $\mathrm{N}$ & $\mathrm{N}$ & $\mathrm{N}$ & $\mathrm{N}$ & $\mathrm{N}$ & $\mathrm{N}$ \\
\hline Axinopsida orbiculata & & & & + & + & + & + & & & & & $\mathrm{N}$ & $\mathrm{N}$ & $\mathrm{N}$ & $\mathrm{N}$ & $\mathrm{N}$ & $\mathrm{N}$ & $\mathrm{N}$ & $\mathrm{N}$ & $\mathrm{N}$ & $\mathrm{N}$ \\
\hline $\begin{array}{l}\text { Similipecten } \\
\text { greenlandicus }\end{array}$ & & & & + & + & + & + & & & & & & & $\mathrm{N}$ & $\mathrm{N}$ & $\mathrm{N}$ & $\mathrm{N}$ & $\mathrm{N}$ & $\mathrm{N}$ & $\mathrm{N}$ & $\mathrm{N}$ \\
\hline CIRRIPEDIA & & & & & & & & & & & & & & & & & & & & & \\
\hline Verruca stroemia & + & + & + & + & + & + & & $\mathrm{X}$ & $\mathrm{X}$ & $\mathrm{X}$ & $\mathrm{X}$ & $\mathrm{X}$ & $\mathrm{X}$ & $\mathrm{X}$ & $\mathrm{X}$ & $\mathrm{X}$ & $\mathrm{X}$ & $\mathrm{X}$ & $\mathrm{X}$ & $\mathrm{X}$ & $\mathrm{X}$ \\
\hline Balanus crenatus & + & + & + & + & + & + & + & $\mathrm{X}$ & $\mathrm{X}$ & $\mathrm{X}$ & $\mathrm{X}$ & $\mathrm{X}$ & $\mathrm{X}$ & $\mathrm{X}$ & $\mathrm{X}$ & $\mathrm{X}$ & $\mathrm{X}$ & $\mathrm{X}$ & $\mathrm{X}$ & $\mathrm{X}$ & $\mathrm{X}$ \\
\hline Balanus balanus & & + & + & + & + & + & + & $\mathrm{X}$ & $\mathrm{X}$ & $\mathrm{X}$ & $\mathrm{X}$ & $\mathrm{X}$ & $\mathrm{X}$ & $\mathrm{X}$ & $\mathrm{X}$ & $\mathrm{X}$ & $\mathrm{X}$ & $\mathrm{X}$ & $\mathrm{X}$ & $\mathrm{X}$ & $\mathrm{X}$ \\
\hline
\end{tabular}

communities (e.g. Amphiura filiformis-A. chiajei community) in the bottomsets at locality 3 . Additional species in- dicate the community of the algal epifauna and hard substrates. 


\section{Zoogeography}

The zoogeographical province division by FeylingHanssen (1955) for shelf areas has commonly been used for interpretation of Quaternary faunas. Troms County is presently in the high-boreal province affected by the warm surface water of the Norwegian current (see FeylingHanssen 1955). Still, the cold waters of the fjords in northwest Norway are known to support arctic species that otherwise only live further north and east (Sars 1878). Living location in a fjord of Troms County also affects the composition (Soot-Ryen 1932). A zoogeographical overview of the obtained species is given in Table 6. The macrofauna probably originated in the high-boreal province. For instance, Acanthocardia echinata and Cerastoderma edule are typical boreal species (e.g. Sars 1878). Species distinctive of the arctic province are also present. For instance, Crenella decussata is most common in the northern parts of its geographical range, particularly in shallow waters (Jensen \& Spärck 1934). This range includes the arctic, boreal and lusitanian provinces (Feyling-Hanssen 1955 and references therein). Traditionally, Mya truncata (Fig. 7G-I) has been considered to be widespread from arctic to boreal seas, and into the northern lusitanian province (e.g. Feyling-Hanssen 1955). Ockelmann (1958), who followed the terminology of Ekman (1953), summarised a panarctic-boreal and circumpolar main distribution as the major occurrence. Later, Petersen (1999) revised the Greenlandic material of the genus Mya and emphasized that M. truncata is a boreal North Atlantic species. This can be critical for assigning some of the investigated samples to a certain province; only few other species are available to specify the exact province (Tab. 6).

The modern fauna at Tromsø was estimated by Grønlie (1945) to have about $50 \%$ species of arctic element, co-occurring with boreal species. Ockelmann (1958) summarised the area north of Lofoten (North Norway) to have about $31 \%$ arctic species and $66 \%$ southern species of total 109 bivalves. This owes to the hydrographical currents bridging the boreal coast of west Norway and the low-artic areas to the north and east (Ockelmann 1958). Living location of the modern fauna in a fjord of Troms County also affects the composition (Soot-Ryen 1932). Biogeographical sector distribution of Norwegian marine prosobranch gastropods, bivalves and barnacles was reviewed by Høisæter et al. (2001a, b) and Sneli \& Brattegard (2001). The distribution indicates that our fossil macrofauna comprises species still living in Troms County and westernmost Finnmark County (Tab. 6). These are within the recent high-boreal province. Only few species are available in each individual sample to specify a certain part of the province. Generally, the samples contain species limiting them to the boreal province; a number of samples even to the high boreal (Tab. 5). Other samples are indica- tive of $\mathrm{mid} /$ high-boreal or boreal/low-arctic provinces (Tab. 5). There is consequently no indication of zoogeographical changes during the Holocene (Tab. 2). Investigating gravity cores from the shelf off Troms and west Finnmark, Vorren et al. (1978) concluded that high-boreal conditions had prevailed during the Holocene. This view is supported by our macrofaunal findings from the fjord delta successions (Tabs 5, 6). Mid-boreal conditions might have occurred in a part of Holocene (Vorren et al. 1978), for which we do not have any direct evidence. A major faunal change offshore North Norway was probably caused by the intrusion of warm, saline, nutrient-rich Atlantic water masses into the Norwegian Current for about 10,000 years $\mathrm{BP}$, with the change from a low-arctic to high-boreal fauna at that time, based on core samples from Andfjorden and Malangsdjupet, North Norway (Thomsen \& Vorren 1986). Further south, the Atlantic Current entered the Norwegian Sea 13,000-13,700 years BP (Ruddiman \& McIntyre 1973), and it swept along western Norway prior to 12,600 years BP (Mangerud 1977). Our radiocarbon dated shells of Macoma calcarea from locality 5 indicate Allerød and Younger Dryas (Tab. 2). Previously, the Stormo area in the midst of the Breivikeidet Valley has yielded Portlandia arctica and Macoma calcarea of Allerød age, in laminated bluish-grey clay of glaciomarine origin (Holmes \& Andersen 1964, Andersen 1968; Tab. 2). Macoma calcarea has a broad distribution in the present boreal and arctic provinces. As stated by Vorren et al. (1978), high/mid arctic conditions might have occurred during Younger Dryas.

\section{Conclusions}

Early Holocene fjord deltaic successions in the Breivikeidet Valley, Troms County were represented by shell materials of 27, 10 and 4 taxa of identified bivalves, gastropods and barnacles, respectively. The most common species are Macoma calcarea, Mya truncata and Mytilus edulis, in descending order. The shells have higher preservation potential in the muddy prodelta deposits than in the delta slope sand.

The macrofauna is a useful proxy for inferring the abiotic conditions of the depositional setting. Bathymetric ranges of the species indicate shallow water. The recent counterparts to the prevalent benthic communities live in shallow waters, in a depth of 10-60 m. Our findings agreed with the previous sclerochronological deductions implying that the bivalves have inhabited the shallow fjord delta receiving North Atlantic influence. Salinity was near normal marine during the deposition of the muddy bottomsets. The deltaic sandy foresets developed under normal marine to brackish conditions and are dominated by euryhaline species. The sandy and gravely topsets are river deposits 
formed under a strong influence of fluvial waters. This change in salinity is also expressed in TOC/TS ratios indicating a progradation from marine, brackish to freshwater depositional conditions. The overall fauna indicates the high-boreal province, which is supported individually by a number of samples. This is consistent with observations of modern marine populations in this part of Norway, and with prior shelf investigations offshore west and north of our study area.

\section{Acknowledgements}

The Julie von Müllen's Foundation (The Royal Danish Academy of Sciences and Letters) and the Christian and Ottilia Brorson's Travel Scholarship for Younger Men and Women within Science are thanked for financial support to Jan K. Nielsen. The Department of Geology, UiT - The Arctic University of Norway, is acknowledged by Jan K. Nielsen for the hospitality during research stays. The work of Samuli Helama has been supported by the Academy of Finland. Jan Petter Holm (UiT - The Arctic University of Norway) kindly drew the basic map in Fig. 1. Geoffrey Corner (UiT - The Arctic University of Norway) and Jesper Hansen (Akvaplan-niva AS, Tromsø) are acknowledged for constructive comments on sedimentology and taxonomy, respectively. We also thank Sergio Martínez (Universidad de la República de Uruguay, Montevideo) and an anonymous for review comments.

\section{References}

Andersen, B.G. 1968. Glacial geology of western Troms, North Norway. Norges Geologiske Undersøkelse 256, 1-160.

Anwar, N.A., Richardson, C.A. \& SEed, R. 1990. Age determination, growth rate and population structure of the horse mussel (Modiolus modiolus). Journal of the Marine Biological Association of the United Kingdom 70, 441-457. DOI 10.1017/S0025315400035529

Aure, J., Føyn, L. \& Pettersen, R. 1996. Miljøundersøkelser i norske fjorder 1975-1994. 3. Nord-Troms: Tromøsundet, Ullsfjord, Lyngenfjord og Kvænangen [Environmental monitoring of Norwegian fjords 1975-1994. 3. Nord-Troms: Tromøsundet, Ullsfjord, Lyngenfjord and Kvænangen]. Fisken og Havet 28, 1-69.

Berner, R.A. \& RAISwEll, R. 1984. C/S method for distinguishing fresh-water from marine sedimentary rocks. Geology 12, 365-368.

DOI 10.1130/0091-7613(1984)12<365:CMFDFF>2.0.CO;2

Boesch, D.F. \& RosenberG, R. 1981. Response to stress in marine benthic communities, 179-200. In Barrett, G.W. \& RosenberG, R. (eds) Stress Effects on Natural Ecosystems. John Wiley, Chichester.

Broch, H. 1924. Cirripedia Thoracica von Norwegen und dem norwegischen Nordmeere. Eine Systematische und Biologisch-Tiergeographische Studie. Videnskapsselskapets
Skrifter. I, Matematisk-naturvidenskabelig klasse, 17, $1-121$.

Bronk RAmSEY, C. 2009. Bayesian analysis of radiocarbon dates. Radiocarbon 51, 337-360. DOI 10.1017/S0033822200033865

BRown, T. 1827. Illustrations of the recent conchology of Great Britain and Ireland. 125 pp. D. Lizars, Edinburgh.

Bruguière, J.G. 1789. Encyclopédie méthodique. Histoire naturelle des vers. 1, 757 pp. Panckoucke, Paris.

Corner, G.D. 1980. Preboreal deglaciation chronology and marine limits of the Lyngen-Storfjord area, Troms, North Norway. Boreas 9, 239-249.

DOI 10.1111/j.1502-3885.1980.tb00700.x

Corner, G.D. \& FJalstad, A. 1993. Spreite trace fossils (Teichichnus) in a raised Holocene fjord-delta, Breidvikeidet, Norway. Ichnos 2, 155-164.

DOI 10.1080/10420949309380085

Corner, G.D. \& Haugane, E. 1993. Marine-lacustrine stratigraphy of raised costal basins and postglacial sea-level change at Lyngen and Vanna, Troms, northern Norway. Norsk Geologisk Tidskrift 73, 175-197.

Corner, G.D., Nordahl, E., Munch-Ellingsen, K. \& Robertsen, K.R. 1990. Morphology and sedimentology of an emergent fjord-head Gilbert-type delta: Alta delta, Norway, 155-168. In Colella, A. \& Prior, D.B. (eds) Coarse-Grained Deltas. International Association of Sedimentologists, Special Publication 10. DOI 10.1002/9781444303858.ch8

Craig, H. 1954. Carbon 13 in plants and the relationships between Carbon 13 and Carbon 14 variations in nature. The Journal of Geology 62, 115-149. DOI 10.1086/626141

Dagestad, A., Tønnesen, J.F. \& DalsegG, E. 2006. Hydrogeologiske undersøkelser ved Ramfjordmoen, Tromsø kommune [Hydrogeological investigations at Ramfjordmoen, Tromsø municipality]. Norges Geologiske Undersøkelse, Report 2005.079, 1-34.

DARwin, C. 1854a. A Monograph on the sub-class Cirripedia with Figures of all the Species. The Balanido, (or sessile cirripedes); The Verrucidce, etc. 684 pp. The Ray Society, London.

Darwin, C. 1854b. A Monograph on the fossil Balanidce and Verrucidce of Great Britain. 44 pp. The Palæontographical Society, London.

Dufour, S.C. 2005. Gill anatomy and the evolution of symbiosis in the bivalve family Thyasiridae. Biological Bulletin 208, 200-212. DOI 10.2307/3593152

Eilertsen, R.S., Corner, G.D., Aasheim, O. \& Hansen, L. 2011. Facies characteristics and architecture related to palaeodepth of Holocene fjord-delta sediments. Sedimentology 58, 1784-1809. DOI 10.1111/j.1365-3091.2011.01239.x

Ekman, S. 1953. Zoogeography of the Sea. 417 pp. Sidgwick and Jackson, London.

Evison, K. 2012. Sedimentologiske, Paleoøkologiske og Diagenetiske Undersøkelser av Holocene Deltaavleiringer ved Breivikeidet, Troms [Sedimentological, Palaeoecological and Diagenetic Investigations of Holocene Delta Deposits at 
Breivikeidet, Troms]. GEO-3900, 93 pp. Master thesis, University of Tromsø, Tromsø, Norway.

Feyling-Hanssen, R.W. 1955. Stratigraphy of the marine late Pleistocene of Billefjorden, Vestspitsbergen. Skrifter Norsk Polarinstitutt 107, 1-186.

Flessa, K.W. \& Kowalewski, M. 1994. Shell survival and time-averaging in nearshore and shelf environments: estimates from the radiocarbon literature. Lethaia 27, 153-165. DOI 10.1111/j.1502-3931.1994.tb01570.x

GBIF 2014a. The Global Biodiversity Information Facility: GBIF Backbone Taxonomy, 2013-07-01. Delectopecten greenlandicus (Sowerby, 1842). Norwegian Biodiversity Information Centre, Natural History Museum, University of Oslo. http://www.gbif.org/species/2285988 on 2014-07-27

GBIF 2014b. The Global Biodiversity Information Facility: GBIF Backbone Taxonomy, 2013-07-01. Phaxas pellucidus (Pennant, 1777). Norwegian Biodiversity Information Centre, Natural History Museum, University of Oslo. Invertebrates (GBIF-SE:SMNH), GBIF-Sweden.

http://www.gbif.org/species/2287245 on 2014-07-30

GBIF 2014c. The Global Biodiversity Information Facility: GBIF Backbone Taxonomy, 2013-07-01. Neptunea despecta (Linnaeus, 1758). Bergen Museum (Gastropoda), Norwegian Biodiversity Information Centre, Natural History Museum, University of Oslo. Invertebrates (GBIF-SE:SMNH), GBIF-Sweden. http://www.gbif.org/species/2304684 on 2014-07-30

Gmelin, J.F. 1791. Caroli a Linné. Systema naturae per regna tria naturae, secundum classes, ordines, genera, species, cum characteribus, differentiis, synonymis, locis. $13^{\text {th }}$ edition, 1(6), 3021-3910. G.E. Beer, Lipsiae.

Grémare, A., Duchêne, J.C., Rosenberg, R., David, E. \& Desmalades, M. 2004. Feeding behaviour and functional response of Abra ovata and A. nitida compared by image analysis. Marine Ecology Progress Series 267, 195-208. DOI 10.3354/meps267195

GrønLIE, O.T. 1945. Postglaciale skjellbanker på Langnes ved Tromsø [Postglacial shell banks on Langnes at Tromsø]. Norsk Geologisk Tidsskrift 25, 159-167.

Hald, M. \& Vorren, T.O. 1983. A shoreline displacement curve from the Tromsø district, North Norway. Norsk Geologisk Tidskrift 63, 103-110.

HedgPeth, J.W. 1957. Estuaries and lagoons. II. Biological aspects. 693-729. In HedGPeth, J.W. (ed.) Treatise on Marine Ecology and Paleocology, Volume 1 Ecology, The Geological Society of America, Memoir 67.

Helama, S., Heikkilä, P., Rinne, K., Nielsen, J.K. \& Nielsen, J.K. 2015. LA-ICP-MS-derived U-concentrations and microstructural domains within biogenic aragonite of Arctica islandica shell. Environmental Monitoring and Assessment 187, article 260. DOI 10.1007/s10661-015-4495-5

Helama, S, Nielsen, J.K., Nielsen, J.K., Hanken, N.M. \& Evison, K. 2014. Preboreal oscillations within the North Atlantic inferred from Arctica islandica sclerochronology. Geobios 47, 305-313.

DOI 10.1016/j.geobios.2014.07.003
Helama, S., Schöne, B.R., Kirchhefer, A.J., Nielsen, J.K., Rodland, D.L. \& JANSSEN, R. 2007. Compound response of marine and terrestrial ecosystems to varying climate: pre-anthropogenic perspective from bivalve shell growth increments and tree-rings. Marine Environmental Research 63, 185-199. DOI 10.1016/j.marenvres.2006.08.003

HiLmo, B.O. 2011. Grunnvannskartlegging i Tromsø Kommune [Groundwater Mapping in Tromsø Municipality]. 18 pp. Asplan Viak AS, Report VRL46-2011-001.

Holmes, G.W. \& Andersen, B.G. 1964. Glacial chronology of Ullsfjord, northern Norway. U.S. Geological Survey Professional Paper 475, D159-D163.

Hummel, H. 1985. Food-in take of Macoma balthica (Mollusca) in relation to seasonal changes in its potential food on a tidal flat in the Dutch Wadden Sea. Netherlands Journal of Sea Research 19, 52-76.

DOI 10.1016/0077-7579(85)90043-2

HunteR, W.R. 1949. The structure and behaviour of Hiatella gallicana (Lamarck) and H. arctica (L.), with special reference to the boring habit. Proceedings of the Royal Society of Edinburgh. Section B. Biology 63, 271-289.

DOI 10.1017/S0080455X00011930

HurRell, J.W., 1995. Decadal trends in the North Atlantic oscillation, regional temperatures and precipitation. Science 269, 676-679. DOI 10.1126/science.269.5224.676

HurRell, J.W. \& DeSER, C. 2010. North Atlantic climate variability: the role of the North Atlantic oscillation. Journal of Marine Systems 79, 231-244.

DOI 10.1016/j.jmarsys.2009.11.002

HøisÆter, T., Sneli, J.A., Wikander, P.B. \& Brattegard, T. 2001a. Bivalvia, 264-278. In Brattegard, T. \& Holthe, T. (eds) Distribution of Marine, Benthic Macroorganisms in Norway. A Tabulated Catalogue. Directorate for Nature Management, Research Report 2001-3.

HøisÆter, T., Sneli, J.A., Wikander, P.B. \& Brattegard, T. 2001b. Prosobranchia, 230-247. In Brattegard, T. \& Holthe, T. (eds) Distribution of Marine, Benthic Macroorganisms in Norway. A Tabulated Catalogue. Directorate for Nature Management, Research Report 2001-3.

Jensen, A.S. 1901. Studier over nordiske Mollusker [Studies on Nordic molluscs]. Videnskabelige Meddelelser fra den Naturhistoriske Forening i Kjøbenhavn 1900, 133-158.

Jensen, A.S. \& SpÄrck, R. 1934. Bløddyr II. Saltvandsmuslinger [Molluscs II. Saltwater Bivalves]. 280 pp. Dansk Naturhistorisk Forening, G.E.C. Gads Forlag, København. Danmarks Fauna 40.

JøRGENSEN, C.B. 1981. Mortality, growth, and grazing impact on a cohort of bivalve larvae, Mytilus edulis L. Ophelia 20, 185-192. DOI 10.1080/00785236.1981.10426570

KaRTVERKET 2015. Tidevannstabeller. For den Norske Kyst med Svalbard samt Dover, England [Tidal Tables. For the Norwegian Coast with Svalbard and Dover, England]. 89 pp. 79. Årgang 2016.

KercKhof, F. 2002. Barnacles (Cirripedia, Balanomorpha) in Belgian waters, an overview of the species and recent evolutions, with emphasis on exotic species. Bulletin de l'Institut 
Royal des Sciences Naturelles de Belgique, Biologie 72 (Supplement), 93-104.

Kidwell, S.M. \& Bosence, D.W.J., 1991. Taphonomy and time-averaging of marine shelly faunas, 115-209. In Allison, P.A. \& Briggs, D.E.G. (eds) Taphonomy. Releasing the Data Locked in the Fossil Record. Plenum, New York.

KIÆR, H. 1902. Niveauforandring eller transport ved drivis [Level changes or transport by drift ice]. Naturen, Bergens Museum, 1902 (12), 364-367.

KIÆR, H. 1908. Om kvartærtidens marine afleiringer ved Tromsø [About Quaternary marine deposits at Tromsø]. Tromsø $\mathrm{Mu}$ seum Aarshefter 25(1902), 17-44.

Kowalewski, M., Flessa, K.W. \& Hallman, D.P. 1995. Ternary taphograms: triangular diagrams applied to taphonomic analysis. Palaios 10, 478-483. DOI 10.2307/3515049

KRANZ, P.M. 1974. The anastrophic burial of bivalves and its paleoecological significance. Journal of Geology 82, 237-265. DOI 10.1086/627961

LEVENTHAL, J.S. 1995. Carbon-sulfur plots to show diagenetic and epigenetic sulfidation in sediments. Geochimica et Cosmochimica Acta 59, 1207-1211. DOI 10.1016/0016-7037(95)00036-Y

Lindahl, O., Belgrano, A., Davidsson, L. \& Hernroth, B. 1998. Primary production, climatic oscillations, and physico-chemical processes: the Gullmar Fjord time-series data set (1985-1996). ICES Journal of Marine Science 55, 723-729. DOI 10.1006/jmsc.1998.0379

Linnaeus, C. 1758. Systema naturce per regna tria naturce, secundum classes, ordines, genera, species, cum characteribus, differentiis, synonymis, locis. $10^{\text {th }}$ edition, 1 . 824 pp. Laurentii Salvii, Holmiæ.

Linnaeus, C. 1767. Systema naturce per regna tria naturce, secundum classes, ordines, genera, species cum characteribus, differentiis, synonymis, locis. $12^{\text {th }}$ edition, 2. 533-1327 pp. Laurentii Salvii, Holmiæ.

Lynch, J. 1990. Provisional elemental values for eight new geochemical lake sediment and stream sediment reference materials LKSD-1, LKSD-2, LKSD-3, LKSD-4, STSD-1, STSD-2, STSD-3 and STSD-4. Geostandards Newsletter 14, 153-167. DOI 10.1111/j.1751-908X.1990.tb00070.x

Madsen, F.J. 1949. Marine Bivalvia. The Zoology of Iceland 4(63), 1-116.

MANGERUD, J. 1972. Radiocarbon dating of marine shells, including a discussion of apparent age of recent shells from Norway. Boreas 1, 143-172. DOI 10.1111/j.1502-3885.1972.tb00147.x

Mangerud, J. 1977. Late Weichselian sediments containing shells, foraminifera, and pollen, at Ågotnes, western Norway. Norsk Geologisk Tidsskrift 57, 23-54.

Mangerud, J., Bondevik, S., Gulliksen, S., Hufthammer, A.K. \& HøISÆTER, T. 2006. Marine ${ }^{14} \mathrm{C}$ reservoir ages for $19^{\text {th }}$ century whales and molluscs from the North Atlantic. Quaternary Science Reviews 25, 3228-3245.

DOI 10.1016/j.quascirev.2006.03.010

Mangerud, J. \& Gulliksen, S. 1975. Apparent radiocarbon ages of Recent marine shells from Norway, Spitsbergen, and Arctic Canada. Quaternary Research 5, 263-273.

DOI 10.1016/0033-5894(75)90028-9

Marthinussen, M. $1962 .{ }^{14} \mathrm{C}$-datings referring to shore lines, transgressions, and glacial substages in northern Norway. Norges Geologiske Undersøkelse, Arbok 215, 37-67.

Mette, M.J., Wanamaker, A.D. JR., Carroll, M.L., Ambrose, W.G. JR. \& RetelLe, M.J. 2015. Linking large-scale climate variability with Arctica islandica shell growth and geochemistry in northern Norway. Limnology and Oceanography 61, 2016, 748-764. DOI 10.1002/lno.10252

Montagu, G. 1808. Supplement to Testacea Britannica. 183 pp. S. Woolmer, Exeter.

MöLLER, H.P.C. 1842. Index molluscorum Groenlandice. 24 pp. I.G. Salomon, Hafniæ. DOI 10.5962/bhl.title.10433

Morse, J.W. \& Berner, R.A. 1995. What determines sedimentary C-S ratios? Geochimica et Cosmochimica Acta 59, 1073-1077. DOI 10.1016/0016-7037(95)00024-T

MøLLER, J.J. 1987. Shoreline relation and prehistoric settlement in northern Norway. Norsk Geografisk Tidskrift 41, 45-60. DOI 10.1080/00291958708552171

MøLLER, J.J. 1989. Geometric simulation and mapping of Holocene relative sea-level changes in northern Norway. Journal of Coastal Research 5, 403-417.

Møller, J.J., Fualstad, A., Haugane, E., Johansen, K.B. \& LARSEN, V. 1986. Kvartærgeologisk verneværdige områder i Troms [Quaternary geologically worth preserving areas in Troms]. Tromura, Naturvitenskap 49, 1-302.

Müller, O.F. 1776. Zoologiae Danicae prodromus, seu Animalium Danice et Norvegice indigenarum characteres, nomina, et synonyma imprimis popularium. 274 pp. Typiis Hallageriis, Havniæ. DOI 10.5962/bhl.title.63795

MÜLLER, O.F. 1779. Von zwoen wenig bekannten Muscheln, der Schinkenarche und der gerunzelten Mahlermuschel. Beschäftigungen der Berlinischen Gesellschaft naturforschender Freunde 4, 55-59.

Nielsen, J.K. 2004. Taphonomy in the light of intrinsic shell properties and life habits: Marine bivalves from the Eemian of northern Russia. Paläontologische Zeitschrift 78, 53-72. DOI 10.1007/BF03009130

Nielsen, J.K., Hanken, N.-M. \& Nielsen, J.K. 2004. The relationships between early diagenetic calcite concretions and shell dissolution in subaerially exposed Holocene marine sediments, North Norway. Abstracts, Scientific Sessions, $32^{\text {nd }}$ International Geological Congress 32(1), p. 166.

Nielsen, J.K., Helama, S. \& Nielsen, J.K. 2008. Taphonomy of freshwater molluscs in carbonate-poor deposits: a case study of the river pearl mussel in northeastern Finnish Lapland. Norwegian Journal of Geology 88, 103-116.

NydAL, R. 1960. Trondheim natural radiocarbon measurements II. American Journal of Science Radiocarbon Supplement 2, 82-96. DOI 10.1017/S1061592X00020627

Ockelmann, W.K. 1958. The zoology of East Greenland. Meddelelser om Grønland 122, 1-256.

ÓlafsSON, E.B. 1986. Density dependence in suspension-feeding and deposit-feeding populations of the bivalve Macoma 
balthica: a field experiment. Journal of Animal Ecology 55, 517-526. DOI 10.2307/4735

Oliver, P.G., Holmes, A.M., KilleEn, I.J. \& Turner, J.A. 2016. Marine bivalve shells of the British Isles. Amgueddfa CymruNational Museum Wales.

http://naturalhistory.museumwales.ac.uk/britishbivalves

PEACOCK, J.D. 1993. Late Quaternary marine mollusca as palaeoenvironmental proxies: a compilation and assessment of basic numerical data for NE Atlantic species found in shallow water. Quaternary Science Reviews 12, 263-275. DOI 10.1016/0277-3791(93)90082-W

Pennant, T. 1777. British Zoology. Vol. IV. Crustacea. Mollusca. Testacea. 154 pp. Benj. White, London.

Petersen, C.G.J. 1913. Valuation of the sea. II. The animal communities of the sea bottom and their importance for marine zoogeography. Reports of the Danish Biological Station 21, $1-44$.

Petersen, C.G.J. 1914. Appendix to report 21. On the distribution of the animal communities of the sea bottom. Reports of the Danish Biological Station 22, 1-7.

Petersen, C.G.J. 1918. The sea bottom and its production of fish-food. A survey of the work done in connection with valuation of the Danish waters from 1883-1917. Reports of the Danish Biological Station 25, 1-62.

Petersen, C.G.J. 1924. A brief survey of the animal communities in Danish waters, based upon quantitive samples taken with the bottom sampler. American Journal of Science, Series 5, 7, 343-354. DOI 10.2475/ajs.s5-7.41.343

Petersen, G.H. 1958. Notes on the growth and biology of the different Cardium species in Danish brackish water areas. Meddelelser fra Danmarks Fiskeri- og Havundersøgelser, New Series 2(22), 1-31.

Petersen, G.H. 1977. The density, biomass and origin of the bivalves of the Central North Sea. Meddelelser fra Danmarks Fiskeri- og Havundersøgelser 7, 221-273.

Petersen, G.H. 1999. Five Recent Mya species, including three new species and their fossil connections. Polar Biology 22, 322-328. DOI 10.1007/s003000050425

Petersen, G.H. 2001. Studies on some Arctic and Baltic Astarte species (Bivalvia, Mollusca). Meddelelser om Grønland, Bioscience 52,1-71.

Petersen, G.H. \& Russell, P.J.C. 1973. The nomenclature and classification of some European shallow-water Cardium species. Malacologia 14, 233-234.

Petersen, K.S. 2004. Late Quaternary environmental changes recorded in the Danish marine molluscan faunas. Geological Survey of Denmark and Greenland Bulletin 3, 1-196.

Pettersen, K. 1880. Terrasser og gamle strandlinjer [Terraces and old shorelines]. Tromsø Museums Aarshefter 3, 1-52.

PHILIPPI, R.A. 1836. Enumeratio molluscorum Sicilice cum viventium tum in tellure tertiaria fossilium, quae in itinere suo observavit. 1. 267 pp. Schropp, Berolini. DOI 10.5962/bhl.title.100735

PhILIPPI, R.A. 1845. Kritische Bemerkungen über einige Trochus-Arten und die Gattung Axinus. Zeitschrift für Malakozoologie 1845(June), 87-91.
Poulsen, E.M. 1935. De danske farvandes rurer (Balanomorpha og Verrucomorpha) [The Danish waters' barnacles (Balanomorpha and Verrucomorpha)]. Videnskabelige Meddelelser fra Dansk Naturhistorisk Forening 99, 5-27.

Powilleit, M., Graf, G., Kleine, J., Riethmuller, R., Stockmann, K., Wetzel, M.A. \& Koop, J.H.E. 2009. Experiments on the survival of six brackish macro-invertebrates from the Baltic Sea after dredged spoil coverage and its implications for the field. Journal of Marine Systems 75, 441-451. DOI 10.1016/j.jmarsys.2007.06.011

RAISWELl, R. \& BERNER, R.A. 1986. Pyrite and organic matter in Phanerozoic normal marine shales. Geochimica et Cosmochimica Acta 50, 1967-1976.

DOI 10.1016/0016-7037(86)90252-8

RASMUSSEN, E. 1973. Systematics and ecology of the Isefjord marine fauna (Denmark). Ophelia 11, 1-507.

DOI 10.1080/00785326.1973.10430115

ReEs, E.I.S., Nicholaidou, A. \& Laskaridou, P. 1977. The effects of storms on the dynamics of shallow water benthic associations, 465-474. In KeEgan, B.F., O’CeIdigh, P. \& BoAden, P.J.S. (eds) Biology of Benthic Organisms. $11^{\text {th }}$ European Symposium on Marine Biology.

Richardson, C.A., IBARrola, I. \& Ingham, R.J. 1993. Emergence pattern and spatial distribution of the common cockle Cerastoderma edule. Marine Ecology Progress Series 99, 71-81. DOI 10.3354/meps099071

Reimer, P.J., Bard, E., Bayliss, A., Beck, J.W., Blackwell, P.G., Bronk Ramsey, C., Grootes, P.M., Guilderson, T.P., Haflidason, H., Hajdas, I., Hatté, C., Heaton, T.J., Hoffmann, D.L., Hogg, A.G., Hughen, K.A., Kaiser, K.F., Kromer, B., Manning, S.W., Niu, M., Reimer, R.W., RichARDS, D.A., SCOtT, E.M., Southon, J.R., STAFF, R.A., TuRnEy, C.S.M. \& Plicht, J. VAN DER 2013. IntCal13 and Marine13 Radiocarbon age calibration curves 0-50,000 years cal BP. Radiocarbon 55, 1869-1887. DOI 10.2458/azu_js_rc.55.16947

Ruddiman, W.F. \& McIntyre, A. 1973. Time-transgressive deglacial retreat of polar waters from the North Atlantic. Quaternary Research 3, 117-130. DOI 10.1016/0033-5894(73)90058-6

Russell, P.J.C. \& Petersen, G.H. 1973. The use of ecological data in the elucidation of some shallow water European Cardium species. Malacologia 14, 223-232.

SÆLEN, O.H. 1950. The hydrography of some fjords in northern Norway. Balsfjord, Ulfsfjord, Grøtsund, Vengsøyfjord and Malangen. Tromsø Museums Arshefter, Naturhistorisk Avdeling Nr. 38, 70 (1947, No. 1), 1-102.

SARS, G.O. 1878. Bidrag til Kundskaben om Norges arktiske Fauna. I. Mollusca Regionis Arctica Norvegice. Oversigt over de i Norges arktiske Region forekommende Bløddyr [Contribution to the Knowledge about Norway's Arctic Fauna. I. Mollusca Regionis Arctica Norvegice. Overview over Molluscs occurring in Norway's Arctic Region]. 466 pp. A.W. Brøgger, Christiana. DOI 10.5962/bhl.title.42224

SCHÄFER, W. 1962. Aktuo-paläontologie nach Studien in der Nordsee. 666 pp. Verlag Waldemar Kramer, Frankfurt am Main. 
SCHUMACHER, C.F. 1817. Essai d'un nouveau système des habitations des vers testacés. 287 pp. Schultz, Copenhagen.

SCRUTON, P.C. 1960. Delta building and the deltaic sequence, 82-102. In ShePard, F.P., Phleger, F.B. \& van Andel, T.H. (eds) Recent Sediments, Northwest Gulf of Mexico. American Association of Petroleum Geologists, Special Publication 21.

Sneli, J.A. \& Brattegard, T. 2001. Cirripedia, 152-155. In Brattegard, T. \& Holthe, T. (eds) Distribution of Marine, Benthic Macroorganisms in Norway. A Tabulated Catalogue. Directorate for Nature Management, Research Report 2001-3.

Soot-Ryen, T. 1924. Faunistische Untersuchungen im Ramfjorde. Tromsø Museums Aarshefter 45 (1922, No. 6), $1-106$.

SoOt-Ryen, T. 1932. Hydrographical investigations in the Ramfiord 1924-25. Tromsø Museums Arshefter, Naturhistorisk Avdeling Nr. 2, 51 (1928, No. 4), 1-21.

Soot-Ryen, T. 1934. Hydrographical investigations in the Tromsø District 1930. Tromsø Museums Arshefter, Naturhistorisk Avdeling Nr. 3, 52 (1929, No. 1), 1-78.

SowerBy, G.B. II 1842. Thesaurus conchyliorum, or monographs of genera of shells. 1, 438 pp. G.B. Sowerby, junior (ed.), Sowerby, London.

Spengler, L. 1793. Beskrivelse over et nyt Slægt af de toskallede Konkylier, forhen af mig kaldet Chæna, saa og over det Linnéiske Slægt Mya, hvilket nøiere bestemmes, og inddeles i tvende Slægter [Description of a new genus of the bivalved conchs, previously by me called Chæna, also of the Linnean genus $M y a$, which is determined in more details, and divided into two genera]. Skrivter af Naturhistorie-Selskabet 3(1), 16-69.

StePhensen, K. 1933. Havedderkopper (Pycnogonida) og Rankefødder (Cirripedia) [Sea Spiders (Pycnogonida) and Barnacles (Cirripedia)]. Dansk Naturhistorisk Forening, G.E.C. Gads Forlag, København. Danmarks Fauna 38, $1-158$.

TebBLE, N. 1976. British Bivalve Seashells. A Handbook for Identification. 212 pp. British Museum (Natural History), Her Majesty 's Stationary Office, Edinburgh, $2^{\text {nd }}$ edition.

Theisen, B.F. 1973. The growth of Mytilus edulis L. (Bivalvia) from Disko and Thule district, Greenland. Ophelia 12, 59-77. DOI 10.1080/00785326.1973.10430120

Thompson, I., Jones, D.S. \& DreiBelBis, D. 1980. Annual internal growth banding and life history of the ocean quahog Arctica islandica (Mollusca: Bivalvia). Marine Biology 57, 25-34. DOI 10.1007/BF00420964

Thomsen, E. \& VorRen, T.O. 1986. Macrofaunal palaeoecology and stratigraphy in Late Quaternary shelf sediments off northern Norway. Palaeogeography, Palaeoclimatology, Palaeoecology 56, 103-150. DOI 10.1016/0031-0182(86)90110-0

THorson, G. 1933. Investigations on shallow water animal communities in the Franz Joseph Fjord (East Greenland) and adjacent waters. Meddelelser om Grønland 100(2), 1-68.

Thorson, G. 1934. Contributions to the animal ecology of the Scoresby Sound fjord complex (East Greenland). Meddelelser om Grønland 100(3), 1-67.

Thorson, G. 1957. Bottom communities (sublittoral or shallow shelf), 461-534. In Hedgreth, J.W. (ed.) Treatise on Marine Ecology and Paleoecology Vol. I. Geological Society of America Memoir 67. DOI 10.1130/MEM67V1-p461

Vorren, T.O., Strass, I.F. \& Lind-Hansen, O.W. 1978. Late Quaternary sediments and stratigraphy on the continental shelf off Troms and West Finnmark, northern Norway. Quaternary Research 10, 340-365. DOI 10.1016/0033-5894(78)90026-1

WiBorg, K.F. 1962. Haneskjellet, Chlamys islandica (O. F. Müller) og dets utbredelse i noen nordnorske fjorder [The Iceland scallop, Chlamys islandica (O. F. Müller) and its distribution in some northern Norwegian fjords]. Fisken og Havet, Rapporter og Meldinger fra Fiskeridirektoratets Havforskningsinstitutt Bergen, 1963(3), 17-23.

WiBORG, K.F. 1963. Some observations on the Iceland scallop Chlamys islandica (O.F. Müller) in Norwegian waters. Fiskeridirektoratets Skrifter Serie Havundersøkelser 13, $38-53$.

WiKANDER, P.B. 1980. Biometry and behaviour in Abra nitida (Müller) and A. longicallus (Scacchi) (Bivalvia, Tellinacea). Sarsia 65, 255-268. DOI 10.1080/00364827.1980.10431488

WitBAARD, R. 1996. Growth variations in Arctica islandica L. (Mollusca): a reflection of hydrography-related food supply. ICES Journal of Marine Science 53, 981-987. DOI 10.1006/jmsc.1996.0122

WitbaARD, R. \& Bergman, M.J.N. 2003. The distribution and population structure of the bivalve Arctica islandica L. in the North Sea: what possible factors are involved? Journal of Sea Research 50, 11-25.

DOI 10.1016/S1385-1101(03)00039-X 